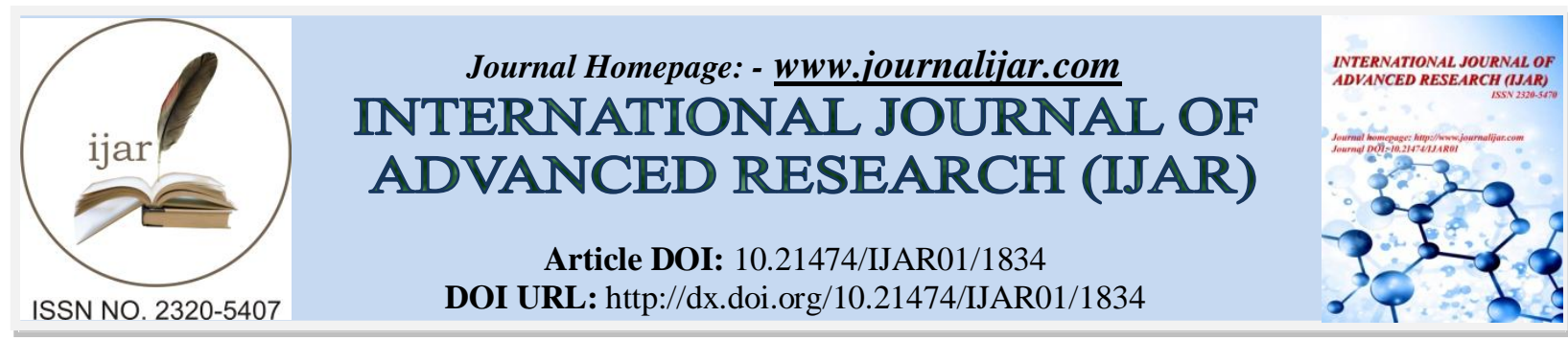

RESEARCH ARTICLE

\title{
LIGNIN MODIFYING ENZYMES OF LIGNICOLOUS FUNGI FROM RATHANMAHAL WILDLIFE SANCTUARY, GUJARAT, INDIA.
}

Praveen Kumar Nagadesi ${ }^{1}$ and Arun Arya ${ }^{2}$.

1. Department of Botany, P.G. section, Andhra Loyola College, Vijayawada -520008, Andhra Pradesh, India.

2. Department of Botany, Faculty of Science, The Maharaja Sayajirao University of Baroda, Vadodara - 390002, Gujarat, India.

\section{Manuscript Info}

\section{Manuscript History}

Received: 12 August 2016

Final Accepted: 22 September 2016

Published: October 2016

Key words:-

Lignin Modifying Enzymes, Lenzites sterioides, Navisporus floccosus,

Lignicolous fungi, Fungal Aryl Alcohol Oxidase

\section{Abstract}

Lignicolous basidiomycetes are highly specialized organisms that are capable of degrading lignin, one of the most abundant and resistant organic compounds. Through their enzymes and secondary metabolites, these fungi have a great potential that can be successfully used in various biotechnological processes, ranging from mycoremediation of different pollutants and isolation of bioactive molecules with applications in the pharmacological industry and agriculture, as biocontrol agents of phytopathogens. The importance of lignicolous fungi and their ligninolytic enzymes has been well appreciated globally. So lignicolous fungi from Rathanmahal Wildlife Sanctuary, Gujarat, India were tested for presence of Lignin Modifying Enzymes and effect of nitrogen on enzymatic activity. Basal medium containing $\mathrm{KNO}_{3}, \mathrm{NaNO}_{3}, \mathrm{Ca}\left(\mathrm{NO}_{3}\right)_{2}$ and $\mathrm{NH}_{4}\left(\mathrm{NO}_{3}\right)_{2}$, was used to test the efficacy of ligninolytic activity. The highest aryl alcohol oxidase activity was observed in case of basal medium supplemented with $\mathrm{NH}_{4}\left(\mathrm{NO}_{3}\right)_{2}$ i.e. $6.85 \mathrm{U} / \mathrm{ml}$ whereas lowest in case of $\mathrm{NaNO}_{3}$ i.e. $0.15 \mathrm{U} / \mathrm{ml}$. highest laccase activity was observed in basal medium containing $\mathrm{NH}_{4}\left(\mathrm{NO}_{3}\right)_{2}$, whereas lowest laccase activity was observed in case of $\mathrm{NaNO}_{3}$. The highest lignin peroxidase activity was observed in presence of $\mathrm{NH}_{4}\left(\mathrm{NO}_{3}\right)_{2}$, whereas lowest in case of $\mathrm{Ca}\left(\mathrm{NO}_{3}\right)_{2}$. For the first time effect of Nitrogen on Aryl Alcohol Oxidase activity by Lenzites sterioides, Navisporus floccosus and Flavodon flavus was reported.

Copy Right, IJAR, 2016,. All rights reserved.

\section{Introduction:-}

The term lignicolous fungi have been applied to certain ligninolytic basidiomycetes with a relatively high selectivity to degrade lignin in wood. These fungi produce a set of enzymes which are directly involved in lignin decay. The degree of lignin degradation with respect to other wood components largely depends on the environmental conditions and the fungal species involved. The physiology of L. sepiaria its special reference to enzymatic activity was studies by Zeller (1916). During decay of timber the L. trabum produced lignocellulose degrading enzymes (Gadd, 2001). Some microorganisms produce a complex set of enzymes capable of efficient degradation of native cellulose for example Schizophyllum has efficient cellulase system to degrade the native cellulose. Lignolytic action of $S$. commune was studied by Jurasek (1968) and influence of extractive on cellulase and xylanase activities of $S$. 
commune was studied by Sopko (1968). Two major families of enzymes are involved in ligninolysis by white rot fungi, those are peroxidases and phenol oxidase termed laccase (Leonowicz et al., 2001). Peroxidases divided into lignin peroxidase (LiP), Manganese peroxidase (MnP), (Leonowicz et al., 2001). The activity of extracellular peroxidase depended on a supply of $\mathrm{H}_{2} \mathrm{O}_{2}$. Glucose-1-oxidase (Kelley \& Reddy, 1986), Glucose-2-oxidase (Daniel et al., 1994), Glyoxal oxidase (GLOX) (Kersten \& Kirk, 1987), Aryl Alcohol Oxidase (AAO) (deJong et al., 1994) Aryl alcohol dehydrogenase (AAD) (Muheim et al., 1991) and Methanol Oxidase (Nishida \& Eriksson, 1987) have all been proposed as $\mathrm{H}_{2} \mathrm{O}_{2}$ sources. Each species of white rot fungi secretes a particular assortment of this enzymatic machinery to the medium in which it is growing. Thus some strains produce all of the major families of enzymes, others only two of them or even one (Perez et al., 2002). These results suggest that different enzymatic system, formed by enzymes encoded by different genes, are responsible for lignin degradation by white-rot fungi (Varela $e t$ al., 2000).

The first group, i.e., laccase-active species, was represented by two white-rot fungi, $C$. versicolor and $P$. igniarius. Their laccases oxidized not only syringaldazine, but also o-dianisidine and vanillylacetone. Vanillylacetone is a model lignin compound, whose oxidation may reflect involvement of laccases in the lignin degradation process. The second group of fungi, consisting of a brown-rot fungus $P$. betulinus, two soft rotters, $C$. cellulolyticum and $C$. piluliferum, and a white rotter, $P$. chrysosporium, expressed only peroxidase activities which may be independent or dependent upon the presence of manganese in the medium. The representative of the last group is $L$. trabea, a brown-rot fungus, which did not produce any extracellular enzymes of the oxidase or peroxidase type (Ander and. Eriksson 1978). This finding corroborates the results of Harkin and Obst (1973) who found neither peroxidase nor laccase activity in this species. Some genera of Basidiomycetes, such as Pleurotus spp., were found to lack lignin peroxidases (Fukushima and Kirk 1995), Lentinus edodes showed laccase, but not LiP activity (Leatham and Stahmann, 1981).

\section{Materials and Methods:- Study area:-}

Ratanmahal Wildlife Sanctuary (RWLS) is a relatively small area of $55.65 \mathrm{sq} \mathrm{km}$ consisting of dry deciduous forest. The total existing sanctuary area lies between the river Panam and Orsang. The 11 villages of Ratanmahal forest are situated at the southernmost part of Limkheda taluka of Dahod district of Gujarat state. It is situated between $70^{\circ} 37^{\prime}$ to $74^{\circ} 11^{\prime \prime}$ East Longitude and between $22^{\circ} 32^{\prime \prime}$ to $22^{\circ} 35^{\prime}$ North Latitude. The climate is sub-tropical arid, which turns damp and humid during monsoon. Minimum and maximum rainfall ranges between $957 \mathrm{~mm}$ to $2101 \mathrm{~mm}$. A survey was undertaken in RWLS for collection of samples from living trees and fallen branches.

\section{Isolation and identification of fungi:-}

The young fruit bodies of lignicolous fungi were collected from Ratanmahal Wildlife sanctuary, Gujarat. Wood chips measuring $5 \mathrm{~mm} \times 5 \mathrm{~mm} \times 2 \mathrm{~mm}$ were aseptically removed from the fruit bodies and transferred to petriplates containing cultural media: $2 \%$ malt extract agar amended with $250 \mu \mathrm{g}$ Streptomycin sulphate per ml. Eight pieces were removed from each sample and placed in 2 petriplates. These plates were incubated at $25 \pm 2^{\circ} \mathrm{C}$ for 7 days. Once fungal colonies were formed in the agar plates, each colony was transferred to a new agar slant to obtain a pure culture. Identification of these fungi was based on colony feature and their microscopic examination.

\section{Enzymatic test:-}

Five different lignicolous fungi were isolated from RWLS, Gujarat, India were selected for enzymatic studies. The screening of all species of fungi for their lignolytic and cellulolytic ability was done by substituting the malt extract agar medium (2\%) with tannic acid for ligninase (0.5\%) as suggested by Nobles (1964) and carboxymethyl cellulose for test of cellulase (0.5\%) (Bains et al., 2006).Streptomycin sulphate was added prior to sterilization to avoid bacterial contamination except in case of lignolytic activity where tannic acid itself acts as bactericidal agent. After autoclaving, media was cooled and poured to sterile Petriplates aseptically. On solidification, the plates were inoculated at the center with $1 \mathrm{~cm}^{2}$ mycelial disc of different fungal cultures under study and incubated at $28 \pm 1 \mathrm{oC}$ for a week. The replicates were maintained for each set of observations. The respective enzyme activities were evaluated by observing and measuring the zone of clearance if any, found by flooding the plates with visualizing reagent or dye $(0.25 \%$ Congo red) for $15 \mathrm{~min}$ (Teather and Wood 1982) for detection of cellulolytic activity, while the lignolytic activity was assessed by observing brown colored zone around respective fungal colonies. 


\section{Effect of Nitrogen on ligninolytic enzymes:-}

It was used for the growth of test fungi i.e. S. commune, L. sterioides, G. lucidum, N. floccosus, and F. flavus. The Czepek Dox's medium supplemented with four nitrogen sources was used for growth of these fungi. Flasks containing $25 \mathrm{ml}$ of basal medium were autoclaved at $121^{\circ} \mathrm{C}$ temperature for $20 \mathrm{~min}$, inoculated with test fungi and incubated for 5, 10, and 15days. After completion of incubation period, each test fungus was filtered by using Whatman filter paper no 1 . The filtrate was used to determine final $\mathrm{pH}$. The filter papers were dried in oven and weighed to calculate the growth of wood decay fungi.

\section{Enzyme essay:-}

Lignicolous fungi like S. commune, L. sterioides, G. lucidum, $N$. floccosus, and F. flavus, were tested for production of lignin degrading enzymes. Estimation of Laccase, Peroxidase, Aryl alcohol oxidase, and Lignin peroxidase was done by using Guaiacol and veratryl alcohol as substrates. Czepek Dox's Medium supplemented with $\mathrm{KNO}_{3}$, $\mathrm{NaNO}_{3}, \mathrm{NH}_{4}\left(\mathrm{NO}_{3}\right)_{2}$, and $\mathrm{Ca}\left(\mathrm{NO}_{3}\right)_{2}$ was used for growth of these fungi. Same procedure was followed as described in effect of nitrogen sources on growth with some modifications i.e. the filtrate was centrifuged at $10000 \mathrm{rpm}$ for 15 min to get the clear supernatant. The supernatant was used as crude enzyme source for all ligninolytic enzyme assays.

\section{Laccase Activity:-}

It was assayed according to the procedure suggested by Coll et al., (1993). For measuring laccase activity, source enzyme was added to $50 \mathrm{mM}$ Na-acetate buffer ( $\mathrm{pH} 4.5$ ) containing $1 \mathrm{mM}$ guaiacol (Sigma grade.) as substrate, to make a final volume of $5 \mathrm{ml}$. The tubes were incubated at $37^{\circ} \mathrm{C}$ for $15 \mathrm{~min}$. The blank contained substrate and the source enzyme that was inactivated by boiling. The optical density of the reaction tubes was measured against reagent blank in a Jenway 6105 spectrophotometer at $465 \mathrm{~nm}$ wavelength. One unit relative enzyme activity was described as the amount of enzyme causing a 0.1 unit increase in the optical density of the reaction mixture under the experimental conditions.

\section{Aryl-alcohol oxidase activity (AAO):-}

It was assayed to the procedure suggested by Mansur et al., (2003). The AAO activity was assayed spectrophotometrically, as the oxidation of veratryl (3,4dimethoxybenzyl) alcohol to veratraldehyde, monitored at

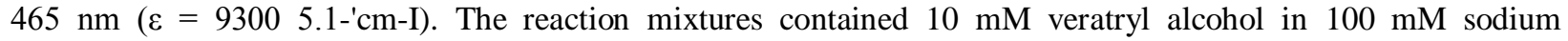
phosphate, $(\mathrm{pH} 6.0)$. One $U$ of enzyme activity is defined as the arnount of enzyme releasing $1 \mu \mathrm{mol} / \mathrm{min}-$ - oxidized $^{\circ}$ product at $25^{\circ} \mathrm{C}$ in enzymatic determination.

\section{Lignin peroxidase (LiP) Activity:-}

it was measured using the method of Tien and Kirk (1984). In this method the increase of absorbance at $310 \mathrm{~nm}$, due to the oxidation of the veratryl alcohol to veratryl aldehyde, was measured. The reaction mixture contained: $2.2 \mathrm{ml}$ of sodium tartrate buffer $\left(50 \mathrm{mM}, \mathrm{pH} 4,5\right.$ at $\left.25^{\circ} \mathrm{C}\right), 40 \mu \mathrm{l}$ of veratryl alcohol $(2 \mathrm{mM})$ and $240 \mu \mathrm{l}$ of culture supernatant. The reaction was initiated by the addition of $20 \mu \mathrm{l}$ of $\mathrm{H}_{2} \mathrm{O}_{2}(0.2 \mathrm{mM})$. The absorbance was measured immediately $(\varepsilon 310=9333 \mathrm{M}-1 \mathrm{~cm}-1)$. One unit enzymatic activity was defined as the quantity of enzyme that produced $1 \mu \mathrm{m}$ of oxidized product.

\section{Peroxidase activity:-}

The enzyme activity was determined using guaiacol as substrate (Lewis et al. 1987). The assay mixture consisted of $0.1 \mathrm{M}$ potassium phosphate buffer ( $\mathrm{pH} 7.0$ at $25^{\circ} \mathrm{C}$ ), $50 \mu \mathrm{l}$ of $20.1 \mathrm{mM}$ guaiacol (Fluka) solution, and the enzyme. The reaction was initiated by the addition of $30 \mu \mathrm{l}$ of $12.3 \mathrm{mM} \mathrm{H}_{2} \mathrm{O}_{2}$. The total volume of the reaction mixture was $3.18 \mathrm{ml}$. Activity was monitored using a spectrophotometer at $436 \mathrm{~nm}$. The enzyme activity was calculated by using an extinction coefficient $(436 \mathrm{~nm})$ of $6.39 \mathrm{~cm}^{2} / \mathrm{pmol}$ for guaiacol. One unit of enzyme activity is defined as $1 \mathrm{pmol}$ of guaiacol consumed (oxidized) per min.

\section{Results:-}

\section{Isolation and identification of fungi:-}

Five different lignicolous fungi were isolated from different woods present in Ratanmahal Wildlife Sanctuary, Gujarat, India. They were identified as Schizophyllum commune, Ganoderma lucidum, Lenzites sterioides, Navisporus floccosus and Flavodon flavus. Pure cultures were maintained on Malt extract medium. 


\section{Enzymatic test:-}

lignicolous fungi like S. commune, L. sterioides, G. lucidum, N. floccosus, and F. flavus were tested for cellulolytic and ligninolytic activity Table 1 . All the lignicolous fungi showed positive test for cellulolytic and ligniolytic activity. The highest cellulolytic activity was shown by S. commune, and F. flavus. The highest ligninolytic activity was shown by G. lucidum.

\section{Effect of Nitrogen on ligninolytic enzymes:-}

The effect of 5 different nitrogen sources was observed in case of 5 wood rotting fungi, the results are depicted in Table 2. The potassium nitrite showed better growth for G. lucidum and N. floccosus. The final $\mathrm{pH}$ of the medium changed from acidic to slightly alkaline nature. The potassium nitrate showed better growth for $N$. floccosus. The final $\mathrm{pH}$ of the medium is acidic in nature. The sodium nitrate showed better growth in L. sterioides and lowest growth was shown by $N$. floccosus. The final $\mathrm{pH}$ of medium is slightly alkaline in nature. The calcium nitrate as sole nitrogen source showed better growth in $L$. sterioides, S. commune. The final $\mathrm{pH}$ of the medium changed from acidic to neutral nature. The ammonium nitrate as sole nitrogen source showed better growth in $F$. flavus and lowest growth in L. sterioides respectively. The final $\mathrm{pH}$ of the medium changed from more acidic to neutral nature.

Based upon growth supporting ability for $S$. commune the inorganic nitrogen compounds are grouped as Calcium nitrate > Sodium nitrate > Potassium nitrate > Potassium nitrite > Ammonium nitrate. Based upon growth supporting ability for $L$. sterioides the inorganic nitrogen compounds are grouped as Sodium nitrate $>$ Calcium nitrate > Potassium nitrate > Potassium nitrite > Ammonium nitrate. Based upon growth supporting ability for $G$. lucidum the inorganic nitrogen compounds are grouped as Potassium nitrite $>$ Ammonium nitrate $>$ Calcium nitrate $>$ Sodium nitrate $>$ Potassium nitrate. Based upon growth supporting ability for $F$. flavus the inorganic nitrogen compounds are grouped as Ammonium nitrate > Calcium nitrate > Potassium nitrite > Potassium nitrate > Sodium nitrate. Based upon growth supporting ability for $N$. floccosus the inorganic nitrogen compounds are grouped as Potassium nitrite $>$ Potassium nitrate $>$ Calcium nitrate $>$ Ammonium nitrate $>$ Sodium nitrate.

\section{Enzyme essay:-}

Basal medium containing i.e. Czepek Dox's medium containing $\mathrm{KNO}_{3}, \mathrm{NaNO}_{3}, \mathrm{Ca}\left(\mathrm{NO}_{3}\right)_{2}$ and $\mathrm{NH}_{4}\left(\mathrm{NO}_{3}\right)_{2}$, was used to test the efficacy for ligninolytic activity of lignicolous fungi like $S$. commune, L. sterioides, G. lucidum, $N$. floccosus, and $F$. flavus. All the lignicolous fungi were able to produce the lignin modifying enzymes like Laccase, Lignin Peroxidase, Aryl Alcohol Oxidase and Peroxidase in culture medium. The highest laccase activity was observed in basal medium containing $\mathrm{NH}_{4}\left(\mathrm{NO}_{3}\right)_{2}$, whereas lowest laccase activity was observed in case of $\mathrm{NaNO}_{3}$. The highest aryl alcohol oxidase activity was observed in $\mathrm{NH}_{4}\left(\mathrm{NO}_{3}\right)_{2}$ containing basal medium, where as the lowest aryl alcohol oxidase was observed in case of NaNO3. The highest lignin peroxidase activity was observed in presence of $\mathrm{NH}_{4}\left(\mathrm{NO}_{3}\right)_{2}$, whereas lowest in case of $\mathrm{Ca}\left(\mathrm{NO}_{3}\right)_{2}$. The highest peroxidase activity was observed in $\mathrm{KNO}_{3}$ containing basal medium whereas, lowest in case of $\mathrm{Ca}\left(\mathrm{NO}_{3}\right)_{2}$.

It is evident from Tables 3. that $S$. commune showed highest laccase activity in $\mathrm{NH}_{4}\left(\mathrm{NO}_{3}\right)_{2}$ basal medium than other basal medium and lowest in case of $\mathrm{Ca}\left(\mathrm{NO}_{3}\right)_{2}$ basal medium. The highest aryl alcohol oxidase enzyme was observed in $\mathrm{NH}_{4}\left(\mathrm{NO}_{3}\right)_{2}$ medium and lowest in case of $\mathrm{Ca}\left(\mathrm{NO}_{3}\right)_{2}$. The highest lignin peroxidase and peroxidase activity was observed in case of $\mathrm{NH}_{4}\left(\mathrm{NO}_{3}\right)_{2}$ and lowest in case of $\mathrm{Ca}\left(\mathrm{NO}_{3}\right)_{2}$.

In case of $\mathrm{KNO}_{3}$ as sole nitrogen source the laccase activity was increased up to 25 days of incubation i.e. $1.81 \mathrm{U} / \mathrm{ml}$. In case of $\mathrm{NH}_{4}\left(\mathrm{NO}_{3}\right)_{2}$ as sole nitrogen source the laccase activity was increased up to 20 days i. e. $12.05 \mathrm{U} / \mathrm{ml}$ and then decreased to $5.58 \mathrm{U} / \mathrm{ml}$. In case of $\mathrm{Ca}\left(\mathrm{NO}_{3}\right)_{2}$ as sole nitrogen source the laccase activity was increased up to 10 days i. e. $6.71 \mathrm{U} / \mathrm{ml}$ and then decreased to $0.18 \mathrm{U} / \mathrm{ml}$ in 25 days of incubation. In case of $\mathrm{NaNO}_{3}$ as sole nitrogen source the laccase activity was increased up to 15 days i. e. $1.96 \mathrm{U} / \mathrm{ml}$ and then decreased to $0.86 \mathrm{U} / \mathrm{ml}$ in 25 days of incubation.

In case of $\mathrm{KNO}_{3}$ as sole nitrogen source the aryl alcohol oxidase activity was increased up to 10 days of incubation i.e. $3.41 \mathrm{U} / \mathrm{ml}$ and then decreased to $2.25 \mathrm{U} / \mathrm{ml}$ in 25 days of incubation. In case of $\mathrm{NH}_{4}\left(\mathrm{NO}_{3}\right)_{2}$ as sole nitrogen source the aryl alcohol oxidase activity was increased up to 20 days i. e. $6.85 \mathrm{U} / \mathrm{ml}$ and then decreased to $4.49 \mathrm{U} / \mathrm{ml}$. In case of $\mathrm{Ca}\left(\mathrm{NO}_{3}\right)_{2}$ as sole nitrogen source the aryl alcohol oxidase activity was increased up to 15 days i. e. 1.43 $\mathrm{U} / \mathrm{ml}$, then decreased to $0.20 \mathrm{U} / \mathrm{ml}$ in 10 days and then increased to $1.17 \mathrm{U} / \mathrm{ml}$ in 25 days of incubation. In case of $\mathrm{NaNO}_{3}$ as sole nitrogen source the aryl alcohol oxidase activity was increased up to 15 days i. e. $1.45 \mathrm{U} / \mathrm{ml}$ and then decreased to $1.04 \mathrm{U} / \mathrm{ml}$ in 25 days of incubation (Fig. I). 
Fig. I:- Aryl Alcohol oxidase activity of S. commune on different Nitrogen.

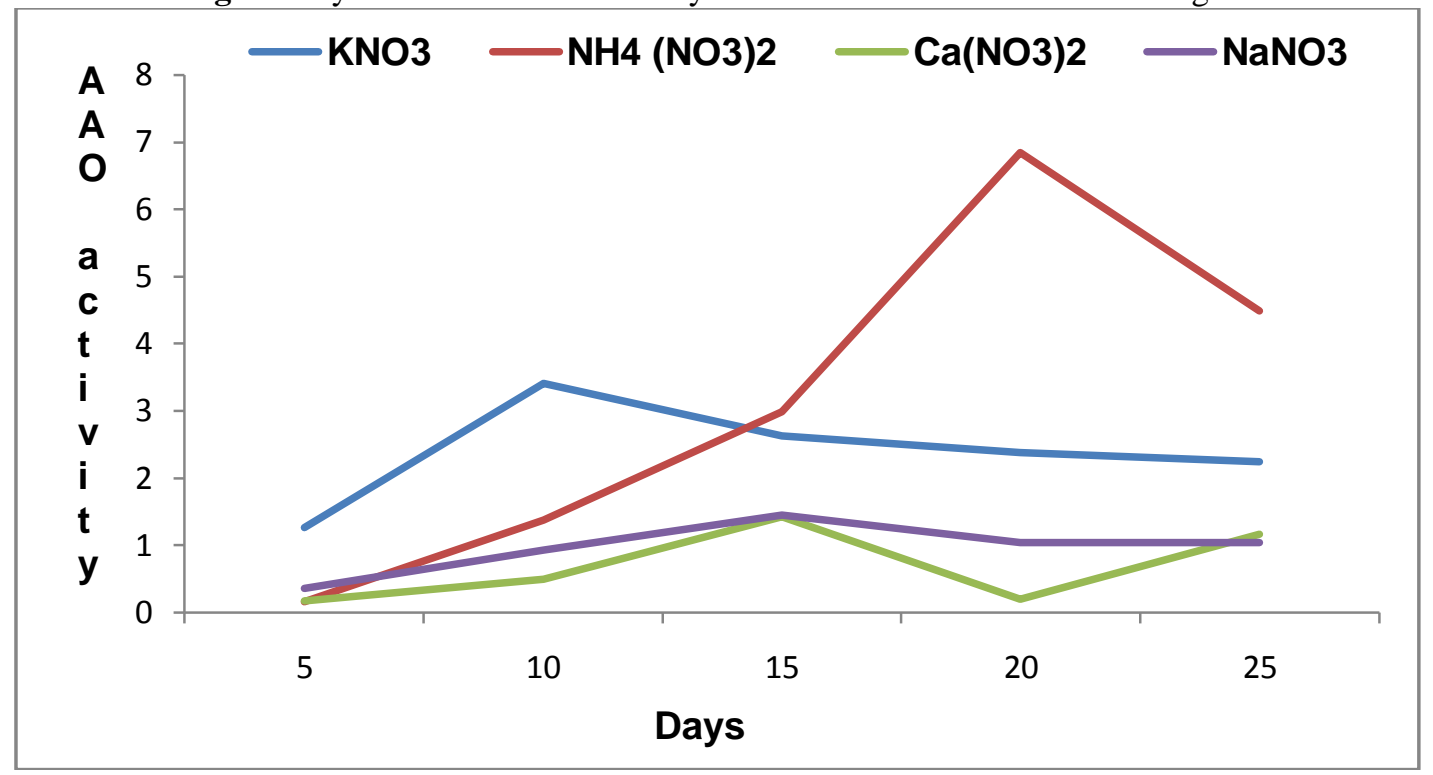

In case of $\mathrm{KNO}_{3}$ as sole nitrogen source the lignin peroxidase activity was increased up to 10 days of incubation i.e. $2.62 \mathrm{U} / \mathrm{ml}$ and decrease to $1.83 \mathrm{U} / \mathrm{ml}$ within 25 days. In case of $\mathrm{NH}_{4}\left(\mathrm{NO}_{3}\right)_{2}$ as sole nitrogen source the lignin peroxidase activity was more when compared to all other lignicolous fungi i. e. $45.50 \mathrm{U} / \mathrm{ml}$ within 20 days. In case of $\mathrm{Ca}\left(\mathrm{NO}_{3}\right)_{2}$ as sole nitrogen source the lignin peroxidase activity was increased up to 10 days i. e. $2.08 \mathrm{U} / \mathrm{ml}$ and then decreased to $0.08 \mathrm{U} / \mathrm{ml}$ in 25 days of incubation which is the least peroxidase activity recorded for this fungi. In case of $\mathrm{NaNO}_{3}$ as sole nitrogen source the lignin peroxidase activity was increased up to 10 days $\mathrm{i}$. e. $9.12 \mathrm{U} / \mathrm{ml}$ and then decreased to $3.83 \mathrm{U} / \mathrm{ml}$ in 25 days of incubation.

In case of $\mathrm{KNO}_{3}$ as sole nitrogen source the peroxidase activity was increased up to 5 days of incubation i.e. 10.52 $\mathrm{U} / \mathrm{ml}$ and then decreased to $3.60 \mathrm{U} / \mathrm{ml}$ within 25 days. In case of $\mathrm{NH}_{4}\left(\mathrm{NO}_{3}\right)_{2}$ as sole nitrogen source the peroxidase activity was increased up to 20 days i. e. $16.64 \mathrm{U} / \mathrm{ml}$. In case of $\mathrm{Ca}\left(\mathrm{NO}_{3}\right)_{2}$ as sole nitrogen source the peroxidase activity was increased up to 20 days i. e. $8.26 \mathrm{U} / \mathrm{ml}$. In case of $\mathrm{NaNO}_{3}$ as sole nitrogen source the peroxidase activity was increased up to 20 days i. e. $4.62 \mathrm{U} / \mathrm{ml}$ and then decreased to $2.76 \mathrm{U} / \mathrm{ml}$ in 25 days of incubation.

It is evident from Tables 4. that L. sterioides showed highest laccase activity incase of $\mathrm{NaNO}_{3}$ whereas lowest in case of $\mathrm{NH}_{4}\left(\mathrm{NO}_{3}\right)_{2}$. The highest aryl alcohol oxidase activity was observed in case of basal medium supplemented with $\mathrm{NH}_{4}\left(\mathrm{NO}_{3}\right)_{2}$ whereas lowest in case of $\mathrm{NaNO}_{3}$. The highest lignin peroxidase was observed in case of $\mathrm{NH}_{4}\left(\mathrm{NO}_{3}\right)_{2}$ whereas lowest in case of $\mathrm{Ca}\left(\mathrm{NO}_{3}\right)_{2}$. The highest peroxidase activity was observed in case of $\mathrm{KNO}_{3}$ whereas lowest in case of $\mathrm{NaNO}_{3}$.

When $\mathrm{KNO}_{3}$ as sole nitrogen source for laccase activity of $L$. sterioides shown increased up to 25 days of incubation i.e. $1.23 \mathrm{U} / \mathrm{ml} ; \mathrm{NH}_{4}\left(\mathrm{NO}_{3}\right)_{2}$ as sole nitrogen source the laccase activity was increased up to $10 \mathrm{days} \mathrm{i}$. e. $1.52 \mathrm{U} / \mathrm{ml}$ and then decreased to $0.13 \mathrm{U} / \mathrm{ml}$ within 25 days; $\mathrm{Ca}\left(\mathrm{NO}_{3}\right)_{2}$ as sole nitrogen source the laccase activity was increased up to 25 days i. e. $0.92 \mathrm{U} / \mathrm{ml}$ and $\mathrm{NaNO}_{3}$ as sole nitrogen source the laccase activity was increased up to 15 days i. e. $4.31 \mathrm{U} / \mathrm{ml}$, then decreased to $1.85 \mathrm{U} / \mathrm{ml}$ in 20 days and increased to $2.26 \mathrm{U} / \mathrm{ml}$ within 25 days.

When $\mathrm{KNO}_{3}$ as sole nitrogen source for Aryl Alcohol Oxidase activity of L. sterioides shown increased up to 25 days of incubation i.e. $1.69 \mathrm{U} / \mathrm{ml} ; \mathrm{NH}_{4}\left(\mathrm{NO}_{3}\right)_{2}$ as sole nitrogen source the aryl alcohol oxidase activity was increased up to 10 days i. e. $0.97 \mathrm{U} / \mathrm{ml} 0.62 \mathrm{U} / \mathrm{ml}$ within 20 days which indicates that it shows two maximum enzymatic activity peaks; $\mathrm{Ca}\left(\mathrm{NO}_{3}\right)_{2}$ as sole nitrogen source the aryl alcohol oxidase activity was increased up to 20 days i. e. $0.52 \mathrm{U} / \mathrm{ml}$ and $\mathrm{NaNO}_{3}$ as sole nitrogen source the aryl alcohol oxidase activity was increased up to 15 days i. e. 1.82 $\mathrm{U} / \mathrm{ml}$, then decreased to $0.62 \mathrm{U} / \mathrm{ml}$ within 25 days(Fig. II). 
Fig. II:- Aryl Alcohol oxidase activity of L. sterioides on different Nitrogen sources.

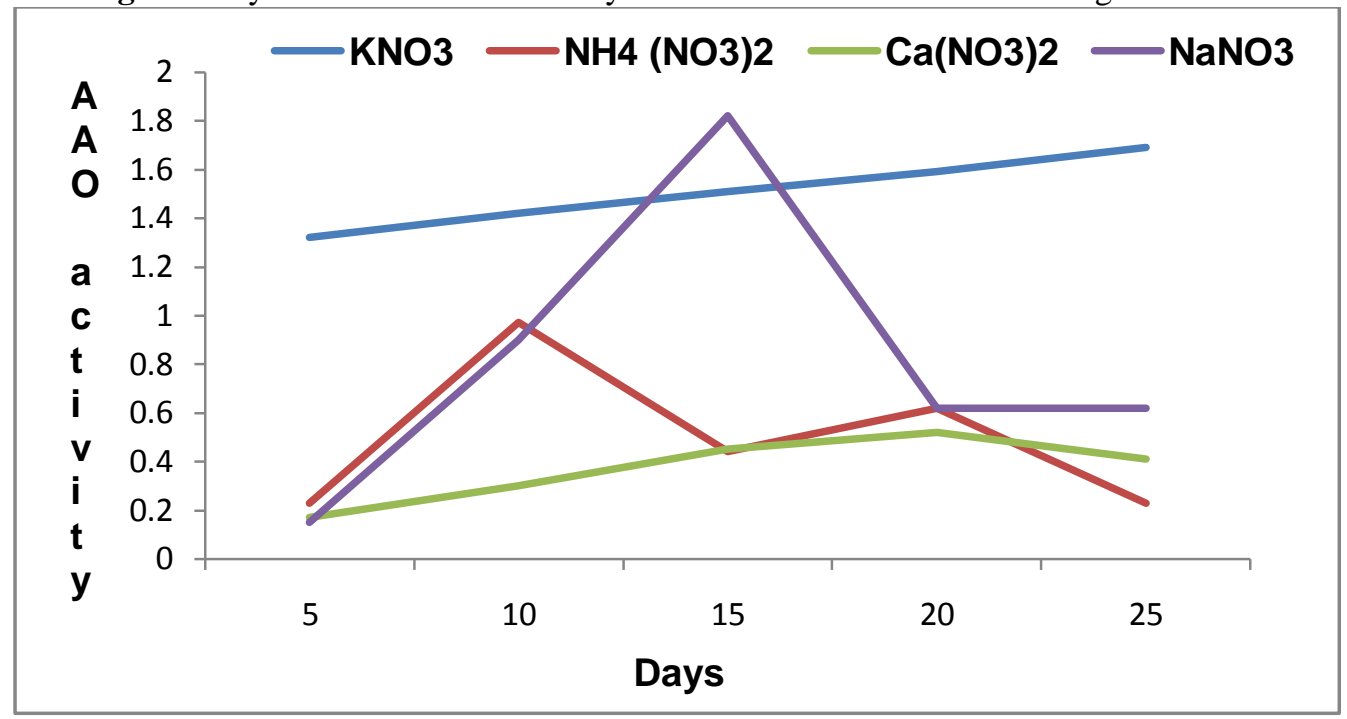

When $\mathrm{KNO}_{3}$ as sole nitrogen source for Lignin Peroxidase activity of L. sterioides shown increased up to 25 days of incubation i.e. $4.20 \mathrm{U} / \mathrm{ml} ; \mathrm{NH}_{4}\left(\mathrm{NO}_{3}\right)_{2}$ as sole nitrogen source the Lignin Peroxidase activity was increased up to 10 days i. e. $15.79 \mathrm{U} / \mathrm{ml}$ and then decreased to $2.00 \mathrm{U} / \mathrm{ml}$ within 25 days; $\mathrm{Ca}\left(\mathrm{NO}_{3}\right)_{2}$ as sole nitrogen source the Lignin Peroxidase activity was increased up to 20 days i. e. $2.33 \mathrm{U} / \mathrm{ml}$ and $\mathrm{NaNO}_{3}$ as sole nitrogen source the Lignin Peroxidase activity was increased up to 15 days i. e. $8.50 \mathrm{U} / \mathrm{ml}$, then decreased to $1.12 \mathrm{U} / \mathrm{ml}$ in 20 days and increased to $4.41 \mathrm{U} / \mathrm{ml}$ within 25 days.

When $\mathrm{KNO}_{3}$ as sole nitrogen source for peroxidase activity of $L$. sterioides shown increased up to 10 days of incubation i.e. $11.48 \mathrm{U} / \mathrm{ml}$ and decreased to $3.64 \mathrm{U} / \mathrm{ml}$ within 25 days; $\mathrm{NH}_{4}\left(\mathrm{NO}_{3}\right)_{2}$ as sole nitrogen source the peroxidase activity was increased up to 15 days i. e. $8.20 \mathrm{U} / \mathrm{ml}$ and then decreased to $0.62 \mathrm{U} / \mathrm{ml}$ within 25 days; $\mathrm{Ca}\left(\mathrm{NO}_{3}\right)_{2}$ as sole nitrogen source the peroxidase activity was increased up to 20 days i. e. $6.64 \mathrm{U} / \mathrm{ml}$ and $\mathrm{NaNO}_{3}$ as sole nitrogen source the peroxidase activity was increased to $5.78 \mathrm{U} / \mathrm{ml}$ within 25 day.

It is evident from Tables 5. that G. lucidum shown highest laccase activity in case of $\mathrm{CaNO}_{3}$ whereas lowest in case of $\mathrm{NaNO}_{3}$. The highest aryl alcohol oxidase activity was observed in case of $\mathrm{KNO}_{3}$ and lowest in case of $\mathrm{NaNO}_{3}$. The highest lignin peroxidase was observed in case of $\mathrm{NH}_{4}\left(\mathrm{NO}_{3}\right)_{2}$ whereas lowest in case of $\mathrm{Ca}\left(\mathrm{NO}_{3}\right)_{2}$. The highest peroxidase activity was observed in case of $\mathrm{KNO} 3$ whereas lowest in case of $\mathrm{NaNO}_{3}$.

When $\mathrm{KNO}_{3}$ as sole nitrogen source, G. lucidum showed ligninolytic activity of laccase enzyme was increased up to 10 days of incubation i.e. $1.75 \mathrm{U} / \mathrm{ml}$ and the decreased to $0.45 \mathrm{U} / \mathrm{ml}$ within 25 days; $\mathrm{NH}_{4}\left(\mathrm{NO}_{3}\right)_{2}$ as sole nitrogen source the laccase activity was increased up to 5 days i. e. $0.95 \mathrm{U} / \mathrm{ml}$ and then decreased to $0.20 \mathrm{U} / \mathrm{ml}$ within 25 days which indicates an early maximum enzymatic activity; $\mathrm{Ca}\left(\mathrm{NO}_{3}\right)_{2}$ as sole nitrogen source the laccase activity was increased up to 10 days i. e. $5.04 \mathrm{U} / \mathrm{ml}$ and then decreased to $0.44 \mathrm{U} / \mathrm{ml}$ within 25 days and $\mathrm{NaNO}_{3}$ as sole nitrogen source the laccase activity was increased up to 15 days i. e. $2.00 \mathrm{U} / \mathrm{ml}$, then decreased to $0.16 \mathrm{U} / \mathrm{ml}$ within 25 days.

When $\mathrm{KNO}_{3}$ as sole nitrogen source, G. lucidum showed ligninolytic activity of aryl alcohol oxidase enzyme was increased up to 10 days of incubation i.e. $2.76 \mathrm{U} / \mathrm{ml}$ and the decreased to $0.83 \mathrm{U} / \mathrm{ml}$ within 25 days; $\mathrm{NH}_{4}\left(\mathrm{NO}_{3}\right)_{2}$ as sole nitrogen source the aryl alcohol oxidase activity was increased up to 5 days i. e. $0.53 \mathrm{U} / \mathrm{ml}$, then decreased to $0.21 \mathrm{U} / \mathrm{ml}$ within 20 days and increased to $0.34 \mathrm{U} / \mathrm{ml}$ within 25 days, which indicates an early maximum enzymatic activity followed by decline and raising to maximum activity; $\mathrm{Ca}\left(\mathrm{NO}_{3}\right)_{2}$ as sole nitrogen source the aryl alcohol oxidase activity was increased up to 10 days i. e. $0.57 \mathrm{U} / \mathrm{ml}$ and then decreased to $0.28 \mathrm{U} / \mathrm{ml}$ within 25 days and $\mathrm{NaNO}_{3}$ as sole nitrogen source the aryl alcohol oxidase activity was increased up to 15 days i. e. $0.85 \mathrm{U} / \mathrm{ml}$, then decreased to $0.18 \mathrm{U} / \mathrm{ml}$ within 25 days(Fig. III). 
Fig. III:- Aryl Alcohol oxidase activity of G. lucidum on different Nitrogen sources.

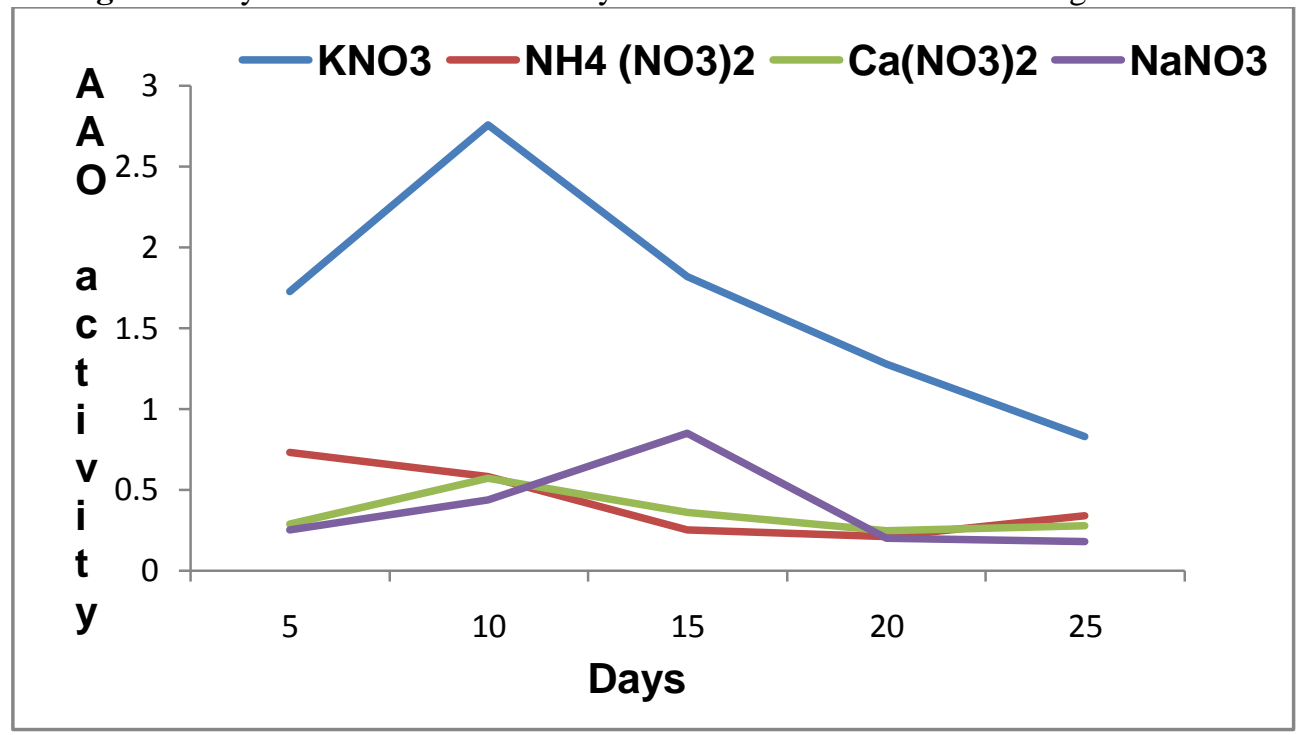

When $\mathrm{KNO}_{3}$ as sole nitrogen source, G. lucidum showed ligninolytic activity of lignin peroxidase enzyme was increased up to 10 days of incubation i.e. $7.08 \mathrm{U} / \mathrm{ml}$ and the decreased to $2.45 \mathrm{U} / \mathrm{ml}$ within 25 days; $\mathrm{NH}_{4}\left(\mathrm{NO}_{3}\right)_{2}$ as sole nitrogen source the lignin peroxidase activity was increased up to 5 days i. e. $9.20 \mathrm{U} / \mathrm{ml}$, decreased to $1.37 \mathrm{U} / \mathrm{ml}$ within 20 days and increased to $2.54 \mathrm{U} / \mathrm{ml}$ within 25 days; $\mathrm{Ca}\left(\mathrm{NO}_{3}\right)_{2}$ as sole nitrogen source the lignin peroxidase activity was increased up to 5 days i. e. $2.75 \mathrm{U} / \mathrm{ml}$ and then decreased to $0.91 \mathrm{U} / \mathrm{ml}$ within 25 days and $\mathrm{NaNO}_{3}$ as sole nitrogen source the lignin peroxidase activity was increased up to 15 days i. e. $5.95 \mathrm{U} / \mathrm{ml}$, then decreased to $1.66 \mathrm{U} / \mathrm{ml}$ within 25 days.

When $\mathrm{KNO}_{3}$ as sole nitrogen source, G. lucidum showed ligninolytic activity of peroxidase enzyme was increased up to 10 days of incubation i.e. $17.9 \mathrm{U} / \mathrm{ml}$ and the decreased to $1.64 \mathrm{U} / \mathrm{ml}$ within 25 days; $\mathrm{NH}_{4}\left(\mathrm{NO}_{3}\right)_{2}$ as sole nitrogen source the peroxidase activity was increased up to 5 days i. e. $4.28 \mathrm{U} / \mathrm{ml}$ and then decreased to $1.10 \mathrm{U} / \mathrm{ml}$ within 25 days which indicates an early maximum enzymatic activity; $\mathrm{Ca}\left(\mathrm{NO}_{3}\right)_{2}$ as sole nitrogen source the peroxidase activity was increased up to 20 days i. e. $7.34 \mathrm{U} / \mathrm{ml}$ and then decreased to $2.78 \mathrm{U} / \mathrm{ml}$ within 25 days and $\mathrm{NaNO}_{3}$ as sole nitrogen source the peroxidase activity was increased up to 15 days i. e. $5.08 \mathrm{U} / \mathrm{ml}$, then decreased to $4.20 \mathrm{U} / \mathrm{ml}$ within 25 days.

It is evident from Tables 6 . that $N$. floccosus showed highest laccase activity in case of $\mathrm{NH}_{4}\left(\mathrm{NO}_{3}\right)_{2}$ and lowest in case of basal medium supplemented with $\mathrm{Ca}\left(\mathrm{NO}_{3}\right)_{2}$. The highest aryl alcohol oxidase activity was observed in case of $\mathrm{KNO}_{3}$ and lowest in case of $\mathrm{Ca}\left(\mathrm{NO}_{3}\right)_{2}$ basal medium. The highest lignin peroxidase was observed in case of $\mathrm{NaNO}_{3}$ whereas lowest in case of $\mathrm{Ca}\left(\mathrm{NO}_{3}\right)_{2}$. The highest peroxidase activity was observed in case of $\mathrm{KNO}_{3}$ whereas lowest in case of $\mathrm{Ca}\left(\mathrm{NO}_{3}\right)_{2}$.

When $\mathrm{KNO}_{3}$ as sole nitrogen source, $N$. floccosus showed ligninolytic activity of laccase enzyme was increased up to 5 days of incubation i.e. $1.12 \mathrm{U} / \mathrm{ml}$ and the decreased to $0.40 \mathrm{U} / \mathrm{ml}$ within 20 days again increased to $1.00 \mathrm{U} / \mathrm{ml}$ within 25 days; $\mathrm{NH}_{4}\left(\mathrm{NO}_{3}\right)_{2}$ as sole nitrogen source the laccase activity was increased up to 5 days i. e. $1.98 \mathrm{U} / \mathrm{ml}$ and then decreased to $0.53 \mathrm{U} / \mathrm{ml}$ within 20 days again increased to $1.07 \mathrm{U} / \mathrm{ml}$ within 25 days, which indicates an early maximum enzymatic activity; $\mathrm{Ca}\left(\mathrm{NO}_{3}\right)_{2}$ as sole nitrogen source the laccase activity was increased up to 15 days i. e. $0.58 \mathrm{U} / \mathrm{ml}$, decreased to $0.09 \mathrm{U} / \mathrm{ml}$ within 20 days and increased to $0.46 \mathrm{U} / \mathrm{ml}$ and $\mathrm{NaNO}_{3}$ as sole nitrogen source the laccase activity was increased up to 15 days i. e. $1.68 \mathrm{U} / \mathrm{ml}$, then decreased to $0.12 \mathrm{U} / \mathrm{ml}$ within 20 days again increased to $0.73 \mathrm{U} / \mathrm{ml}$ within 25 days.

When $\mathrm{KNO}_{3}$ as sole nitrogen source, $N$. floccosus showed ligninolytic activity of aryl alcohol oxidase enzyme was increased up to 5 days of incubation i.e. $2.00 \mathrm{U} / \mathrm{ml}$ and the decreased to $1.14 \mathrm{U} / \mathrm{ml}$ within 25 days; $\mathrm{NH}_{4}\left(\mathrm{NO}_{3}\right)_{2}$ as sole nitrogen source the aryl alcohol oxidase activity was increased up to 5 days i. e. $0.98 \mathrm{U} / \mathrm{ml}$, then decreased to $0.25 \mathrm{U} / \mathrm{ml}$ within 20 days and increased to $0.73 \mathrm{U} / \mathrm{ml}$ within 25 days, which indicates an early maximum enzymatic 
activity followed by decline and raising to maximum activity; $\mathrm{Ca}\left(\mathrm{NO}_{3}\right)_{2}$ as sole nitrogen source the aryl alcohol oxidase activity was increased up to 25 days i. e. $0.30 \mathrm{U} / \mathrm{ml}$ and $\mathrm{NaNO}_{3}$ as sole nitrogen source the aryl alcohol oxidase activity was increased up to 15 days i. e. $1.03 \mathrm{U} / \mathrm{ml}$, then decreased to $0.28 \mathrm{U} / \mathrm{ml}$ within 25 days(Fig. IV).

Fig. IV:- Aryl Alcohol oxidase activity of N. floccosus on different Nitrogen sources.

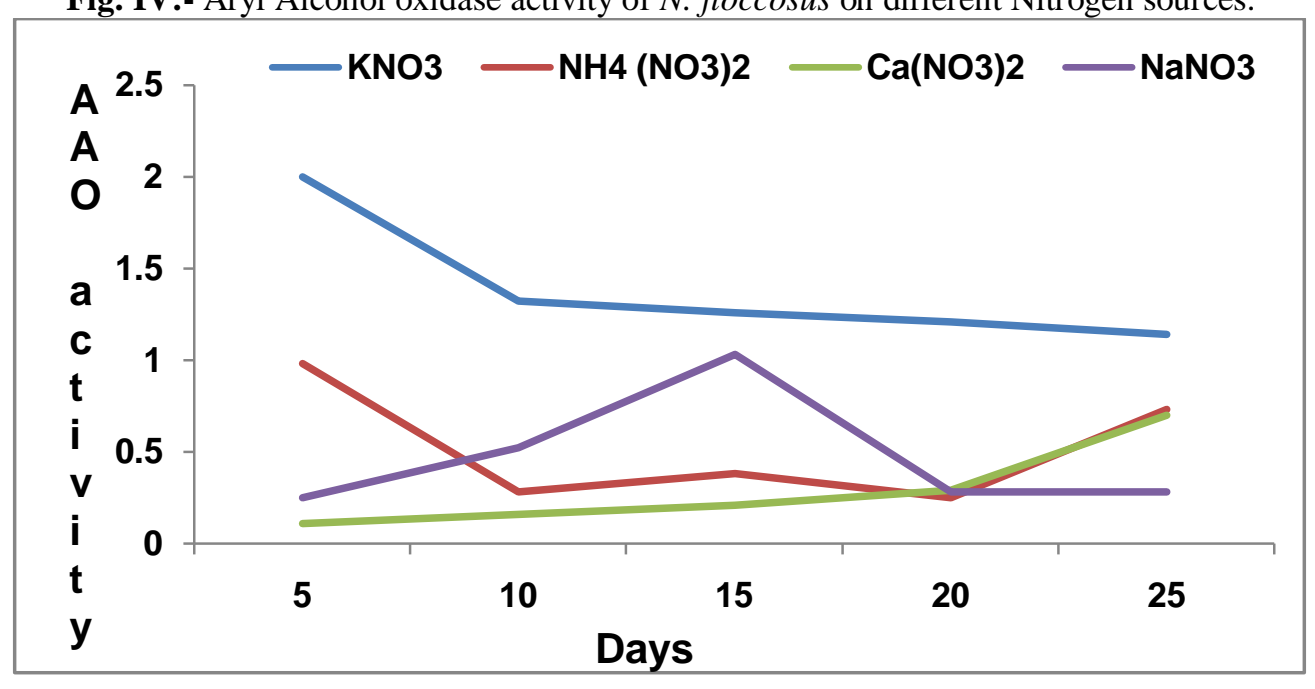

When $\mathrm{KNO}_{3}$ as sole nitrogen source, $N$. floccosus showed ligninolytic activity of lignin peroxidase enzyme was increased up to 5 days of incubation i.e. $3.70 \mathrm{U} / \mathrm{ml}$ and the decreased to $1.45 \mathrm{U} / \mathrm{ml}$ within 25 days; $\mathrm{NH}_{4}\left(\mathrm{NO}_{3}\right)_{2}$ as sole nitrogen source the lignin peroxidase activity was increased up to 5 days i. e. $8.00 \mathrm{U} / \mathrm{ml}$, decreased to $3.75 \mathrm{U} / \mathrm{ml}$ within 20 days and increased to $6.20 \mathrm{U} / \mathrm{ml}$ within 25 days; $\mathrm{Ca}\left(\mathrm{NO}_{3}\right)_{2}$ as sole nitrogen source the lignin peroxidase activity was increased up to 15 days i. e. $1.75 \mathrm{U} / \mathrm{ml}$ and then decreased to $0.08 \mathrm{U} / \mathrm{ml}$ within 25 days and $\mathrm{NaNO}_{3}$ as sole nitrogen source the lignin peroxidase activity was increased up to 15 days i. e. $9.79 \mathrm{U} / \mathrm{ml}$, then decreased to $1.00 \mathrm{U} / \mathrm{ml}$ within 25 days.

When $\mathrm{KNO}_{3}$ as sole nitrogen source, $N$. floccosus showed ligninolytic activity of peroxidase enzyme was increased up to 5 days of incubation i.e. $12.96 \mathrm{U} / \mathrm{ml}$ and the decreased to $2.16 \mathrm{U} / \mathrm{ml}$ within 25 days; $\mathrm{NH}_{4}\left(\mathrm{NO}_{3}\right)_{2}$ as sole nitrogen source the peroxidase activity was increased up to 5 days i. e. $5.54 \mathrm{U} / \mathrm{ml}$, decreased to $4.82 \mathrm{U} / \mathrm{ml}$ within 15 days and increased to $4.90 \mathrm{U} / \mathrm{ml}$ within 25 days it indicates second peak of enzymatic activity; $\mathrm{Ca}\left(\mathrm{NO}_{3}\right)_{2}$ as sole nitrogen source the peroxidase activity was increased up to 20 days i. e. $8.74 \mathrm{U} / \mathrm{ml}$ and then decreased to $0.72 \mathrm{U} / \mathrm{ml}$ within 25 days and $\mathrm{NaNO}_{3}$ as sole nitrogen source the peroxidase activity was increased up to 15 days i. e. 6.52 $\mathrm{U} / \mathrm{ml}$, then decreased to $1.70 \mathrm{U} / \mathrm{ml}$ within 25 days.

It is evident from Tables 7. that $F$. flavus showed highest laccase activity in case of $\mathrm{Na}$ NO3 whereas lowest in case of $\mathrm{Ca}\left(\mathrm{NO}_{3}\right)_{2}$, aryl alcohol oxidase activity in case of $\mathrm{KNO}_{3}$ whereas lowest in case of $\mathrm{Ca}\left(\mathrm{NO}_{3}\right)_{2}$, lignin peroxidase activity in case of $\mathrm{NH}_{4}\left(\mathrm{NO}_{3}\right)_{2}$ whereas lowest in case of $\mathrm{Ca}\left(\mathrm{NO}_{3}\right)_{2}$ and peroxidase activity in case of $\mathrm{KNO}_{3}$ whereas lowest in case of $\mathrm{Ca}\left(\mathrm{NO}_{3}\right)_{2}$.

When $\mathrm{KNO}_{3}$ as sole nitrogen source, $F$. flavus showed ligninolytic activity of Laccase enzyme was increased up to 20 days of incubation i.e. $1.63 \mathrm{U} / \mathrm{ml} ; \mathrm{NH}_{4}\left(\mathrm{NO}_{3}\right)_{2}$ as sole nitrogen source the Laccase activity was increased up to 15 days i. e. $6.32 \mathrm{U} / \mathrm{ml} ; \mathrm{Ca}\left(\mathrm{NO}_{3}\right)_{2}$ as sole nitrogen source the Laccase activity was increased up to 10 days i. e. 8.24 $\mathrm{U} / \mathrm{ml}$ and $\mathrm{NaNO}_{3}$ as sole nitrogen source the Laccase activity was increased up to 20 days i. e. $8.83 \mathrm{U} / \mathrm{ml}$.

When $\mathrm{KNO}_{3}$ as sole nitrogen source, F. flavus showed ligninolytic activity of Aryl Alcohol oxidase enzyme was increased up to 10 days of incubation i.e. $2.63 \mathrm{U} / \mathrm{ml} ; \mathrm{NH}_{4}\left(\mathrm{NO}_{3}\right)_{2}$ as sole nitrogen source the Aryl Alcohol oxidase activity was increased up to 10 days i. e. $1.90 \mathrm{U} / \mathrm{ml} ; \mathrm{Ca}\left(\mathrm{NO}_{3}\right)_{2}$ as sole nitrogen source the Aryl Alcohol oxidase activity was increased up to 10 days i. e. $0.86 \mathrm{U} / \mathrm{ml}$ and $\mathrm{NaNO}_{3}$ as sole nitrogen source the Aryl Alcohol oxidase activity was increased up to 10 days i. e. $1.26 \mathrm{U} / \mathrm{ml}$ (Fig. V). 
Fig. V:- Aryl Alcohol oxidase activity of F. Flavus on different Nitrogen sources.

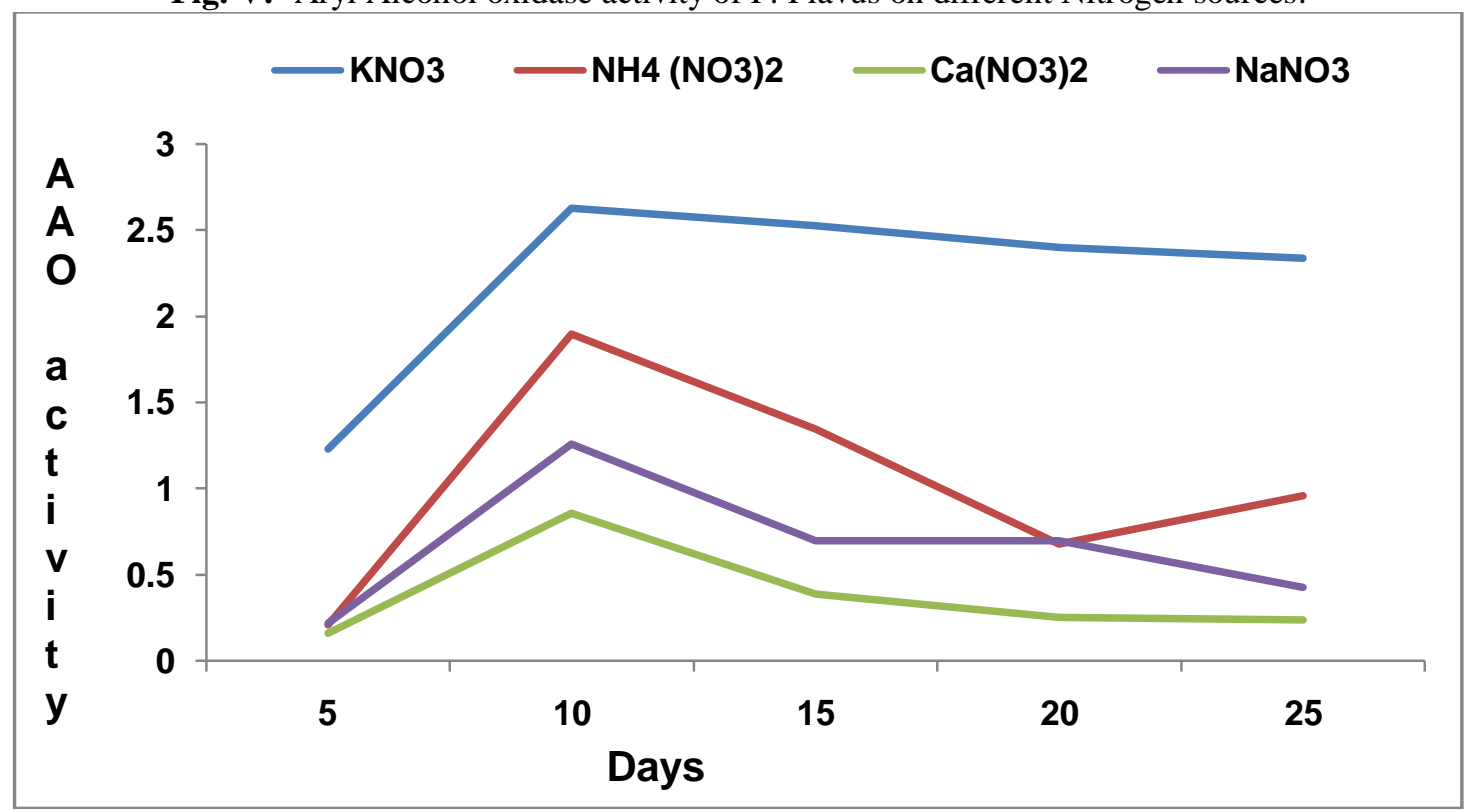

When $\mathrm{KNO}_{3}$ as sole nitrogen source, $F$. flavus showed ligninolytic activity of Lignin Peroxidase enzyme was increased up to 10 days of incubation i.e. $7.33 \mathrm{U} / \mathrm{ml} ; \mathrm{NH}_{4}\left(\mathrm{NO}_{3}\right)_{2}$ as sole nitrogen source the Lignin Peroxidase activity was increased up to 10 days i. e. $21.37 \mathrm{U} / \mathrm{ml} ; \mathrm{Ca}\left(\mathrm{NO}_{3}\right)_{2}$ as sole nitrogen source the Lignin Peroxidase activity was increased up to 10 days i. e. $2.54 \mathrm{U} / \mathrm{ml}$ and $\mathrm{NaNO}_{3}$ as sole nitrogen source the Lignin Peroxidase activity was increased up to 10 days i. e. $11.54 \mathrm{U} / \mathrm{ml}$.

When $\mathrm{KNO}_{3}$ as sole nitrogen source, $F$. flavus showed ligninolytic activity of Peroxidase enzyme was increased up to 10 days of incubation i.e. $14.00 \mathrm{U} / \mathrm{ml} ; \mathrm{NH}_{4}\left(\mathrm{NO}_{3}\right)_{2}$ as sole nitrogen source the Peroxidase activity was increased up to 10 days i. e. $7.10 \mathrm{U} / \mathrm{ml} ; \mathrm{Ca}\left(\mathrm{NO}_{3}\right)_{2}$ as sole nitrogen source the Peroxidase activity was increased up to 20 days $\mathrm{i}$. e. $8.48 \mathrm{U} / \mathrm{ml}$ and $\mathrm{NaNO}_{3}$ as sole nitrogen source the Peroxidase activity was increased up to 20 days i. e. $3.06 \mathrm{U} / \mathrm{ml}$.

Table 1:- Ligninolytic and Cellulolytic activity of different lignicolous fungi.

\begin{tabular}{|l|l|l|l|}
\hline S.No & Lignicolous fungi & Cellulolytic activity* & Lignolytic activity* \\
\hline 1 & Schizophyllum commune & $9 \pm 0.58$ & $5.8 \pm 0.54$ \\
\hline 2 & Lenzites sterioides & $7 \pm 1.0$ & $6.6 \pm 0.32$ \\
\hline 3 & Ganoderma lucidum & $8 \pm 0.56$ & $8.8 \pm 0.53$ \\
\hline 4 & Flavodon flavus & $9 \pm 0.25$ & $4.4 \pm 0.4$ \\
\hline 5 & Navisporus floccosus & $8 \pm 0.45$ & $4.2 \pm 0.67$ \\
\hline
\end{tabular}

*indicates each component values are based on the three replicates

. \pm Results were significant at $\mathrm{P}<.05$ level by one way ANOVA.

Table 2:- Effect of different Nitrogen sources on growth of wood decay fungi.

\begin{tabular}{|l|l|l|l|l|l|l|l|l|l|l|}
\hline & \multicolumn{3}{l}{$\begin{array}{l}\text { Schizophyllum } \\
\text { commune }\end{array}$} & \multicolumn{2}{l|}{$\begin{array}{l}\text { Lenzites } \\
\text { sterioides }\end{array}$} & \multicolumn{2}{l|}{$\begin{array}{l}\text { Ganoderma } \\
\text { lucidum }\end{array}$} & \multicolumn{2}{l|}{ Flavodon flavus } & \multicolumn{2}{l|}{$\begin{array}{l}\text { Navisporus } \\
\text { floccosus }\end{array}$} \\
\hline $\begin{array}{l}\text { Nitrogen } \\
\text { source }\end{array}$ & Dry wt & $\begin{array}{l}\text { Final } \\
\text { pH }\end{array}$ & Dry wt* & $\begin{array}{l}\text { Final } \\
\text { pH }\end{array}$ & Dry wt* & $\begin{array}{l}\text { Final } \\
\text { pH }\end{array}$ & Dry wt* & $\begin{array}{l}\text { Final } \\
\text { pH }\end{array}$ & Dry wt* & $\begin{array}{l}\text { Final } \\
\text { pH }\end{array}$ \\
\hline $\mathrm{KNO}_{2}$ & $160 \pm 3.4$ & 6.20 & $167 \pm 3.4$ & 6.30 & $360 \pm 1.0$ & 4.75 & $175 \pm 1.2$ & 6.25 & $233 \pm 2.5$ & 7.12 \\
\hline $\mathrm{KNO}_{3}$ & $175 \pm 2.8$ & 4.50 & $178 \pm 2.8$ & 4.53 & $125 \pm 2.2$ & 4.60 & $155 \pm 1.8$ & 5.76 & $199 \pm 1.5$ & 5.54 \\
\hline $\mathrm{NaNO}_{3}$ & $215 \pm 1.5$ & 7.30 & $290 \pm 1.5$ & 7.10 & $130 \pm 1.5$ & 6.80 & $120 \pm 1.8$ & 7.15 & $95 \pm 2.8$ & 7.60 \\
\hline $\mathrm{Ca}_{2}\left(\mathrm{NO}_{3}\right)_{2}$ & $259 \pm 2.5$ & 6.50 & $280 \pm 2.5$ & 6.20 & $155 \pm 2.5$ & 5.30 & $185 \pm 1.9$ & 5.10 & $197 \pm 3.4$ & 6.18 \\
\hline $\mathrm{NH}_{4}\left(\mathrm{NO}_{3}\right)_{2}$ & $155 \pm 2.6$ & 3.89 & $121 \pm 2.6$ & 3.58 & $195 \pm 1.7$ & 4.45 & $235 \pm 2.4$ & 6.30 & $162 \pm 3.9$ & 5.18 \\
\hline
\end{tabular}

$*$ indicates each component values are based on the three replicates.

\pm Results were significant at $P<.05$ level by one way ANOVA 
Table 3:- Effect of Nitrogen on ligninolytic activity of $S$. commune

\begin{tabular}{|c|c|c|c|c|}
\hline \multicolumn{5}{|c|}{ Lignin Degrading Enzymes of $S$. commune } \\
\hline \multicolumn{5}{|c|}{ Laccase*U/ml } \\
\hline Days & $\mathrm{KNO}_{3}$ & $\mathrm{NH}_{4}\left(\mathrm{NO}_{3}\right)_{2}$ & $\mathrm{Ca}\left(\mathrm{NO}_{3}\right)_{2}$ & $\mathrm{NaNO}_{3}$ \\
\hline 5 & $0.67 \pm 0.2$ & $0.39 \pm 0.03$ & $0.38 \pm 0.02$ & $0.37 \pm 0.03$ \\
\hline 10 & $0.70 \pm 0.05$ & $6.86 \pm 0.04$ & $6.71 \pm 0.05$ & $1.57 \pm 0.05$ \\
\hline 15 & $0.86 \pm 0.03$ & $11.15 \pm 0.08$ & $1.84 \pm 0.06$ & $1.96 \pm 0.07$ \\
\hline 20 & $1.06 \pm 0.04$ & $12.05 \pm 0.20$ & $0.20 \pm 0.08$ & $1.94 \pm 0.05$ \\
\hline 25 & $1.81 \pm 0.06$ & $5.58 \pm 0.15$ & $0.18 \pm 0.03$ & $0.86 \pm 0.06$ \\
\hline \multicolumn{5}{|c|}{ Aryl Alcohol oxidase* U/ml } \\
\hline 5 & $1.27 \pm 0.04$ & $0.17 \pm 0.04$ & $0.18 \pm 0.04$ & $0.36 \pm 0.04$ \\
\hline 10 & $3.41 \pm 0.06$ & $1.38 \pm 0.02$ & $0.50 \pm 0.02$ & $0.93 \pm 0.05$ \\
\hline 15 & $2.63 \pm 0.05$ & $2.99 \pm 0.08$ & $1.43 \pm 0.08$ & $1.45 \pm 0.07$ \\
\hline 20 & $2.38 \pm 0.03$ & $6.85 \pm 0.30$ & $0.20 \pm 0.07$ & $1.04 \pm 0.08$ \\
\hline 25 & $2.25 \pm 0.01$ & $4.49 \pm 0.20$ & $1.17 \pm 0.05$ & $1.04 \pm 0.05$ \\
\hline \multicolumn{5}{|c|}{ Lignin Peroxidase* $\mathrm{U} / \mathrm{ml}$} \\
\hline 5 & $2.12 \pm 0.02$ & $4.08 \pm 0.1$ & $1.37 \pm 0.03$ & $6.71 \pm 0.2$ \\
\hline 10 & $2.62 \pm 0.05$ & $13.20 \pm 0.2$ & $2.08 \pm 0.05$ & $9.12 \pm 0.3$ \\
\hline 15 & $2.20 \pm 0.04$ & $4.08 \pm 0.32$ & $1.93 \pm 0.07$ & $7.10 \pm 0.5$ \\
\hline 20 & $2.00 \pm 0.01$ & $45.50 \pm 1.2$ & $1.63 \pm 0.08$ & $3.87 \pm 0.7$ \\
\hline 25 & $1.83 \pm 0.04$ & $26.29 \pm 1.5$ & $0.08 \pm 0.08$ & $3.83 \pm 0.3$ \\
\hline \multicolumn{5}{|c|}{ Peroxidase $^{*} \mathrm{U} / \mathrm{ml}$} \\
\hline 5 & $10.52 \pm 0.04$ & $3.38 \pm 0.08$ & $0.82 \pm 0.02$ & $1.58 \pm 0.1$ \\
\hline 10 & $9.56 \pm 0.05$ & $5.32 \pm 0.07$ & $0.84 \pm 0.04$ & $2.44 \pm 0.17$ \\
\hline 15 & $6.40 \pm 0.02$ & $5.82 \pm 0.10$ & $2.54 \pm 0.08$ & $3.08 \pm 0.2$ \\
\hline 20 & $5.16 \pm 0.06$ & $16.64 \pm 0.25$ & $8.26 \pm 0.20$ & $4.62 \pm 0.3$ \\
\hline 25 & $3.60 \pm 0.04$ & $12.74 \pm 0.14$ & $0.70 \pm 0.01$ & $2.76 \pm 0.25$ \\
\hline
\end{tabular}

$*$ indicates each component values are based on the three replicates.

\pm Results were significant at $P<.05$ level by one way ANOVA.

Table 4:- Effect of Nitrogen on ligninolytic activity of $L$. sterioides.

\begin{tabular}{|c|c|c|c|c|}
\hline \multicolumn{5}{|c|}{ Lignin Degrading Enzymes of L. sterioides } \\
\hline \multicolumn{5}{|c|}{ Laccase* $\mathbf{U} / \mathbf{m l}$} \\
\hline Days & $\mathrm{KNO}_{3}$ & $\mathrm{NH}_{4}\left(\mathrm{NO}_{3}\right)_{2}$ & $\mathrm{Ca}\left(\mathrm{NO}_{3}\right)_{2}$ & $\mathrm{NaNO}_{3}$ \\
\hline 5 & $0.84 \pm 0.03$ & $0.28 \pm 0.02$ & $0.37 \pm 0.02$ & $0.30 \pm 0.05$ \\
\hline 10 & $0.92 \pm 0.02$ & $1.52 \pm 0.04$ & $0.43 \pm 0.04$ & $1.01 \pm 0.04$ \\
\hline 15 & $1.05 \pm 0.05$ & $0.42 \pm 0.05$ & $0.76 \pm 0.07$ & $4.31 \pm 0.07$ \\
\hline 20 & $1.13 \pm 0.06$ & $0.33 \pm 0.01$ & $0.83 \pm 0.05$ & $1.85 \pm 0.03$ \\
\hline 25 & $1.23 \pm 0.06$ & $0.13 \pm 0.05$ & $0.92 \pm 0.09$ & $2.26 \pm 0.08$ \\
\hline \multicolumn{5}{|c|}{ Aryl Alcohol oxidase* U/ml } \\
\hline 5 & $1.32 \pm 0.04$ & $0.23 \pm 0.04$ & $0.17 \pm 0.04$ & $0.15 \pm 0.02$ \\
\hline 10 & $1.42 \pm 0.03$ & $0.97 \pm 0.06$ & $0.30 \pm 0.07$ & $0.90 \pm 0.01$ \\
\hline 15 & $1.51 \pm 0.02$ & $0.44 \pm 0.02$ & $0.45 \pm 0.03$ & $1.82 \pm 0.04$ \\
\hline 20 & $1.59 \pm 0.04$ & $0.62 \pm 0.07$ & $0.52 \pm 0.01$ & $0.62 \pm 0.08$ \\
\hline 25 & $1.69 \pm 0.07$ & $0.23 \pm 0.02$ & $0.41 \pm 0.08$ & $0.62 \pm 0.07$ \\
\hline \multicolumn{5}{|c|}{ Lignin Peroxidase* $\mathrm{U} / \mathrm{ml}$} \\
\hline 5 & $1.41 \pm 0.07$ & $7.75 \pm 0.12$ & $0.79 \pm 0.04$ & $0.95 \pm 0.04$ \\
\hline 10 & $1.83 \pm 0.05$ & $15.79 \pm 0.32$ & $0.62 \pm 0.07$ & $2.40 \pm 0.08$ \\
\hline 15 & $2.16 \pm 0.07$ & $2.91 \pm 0.21$ & $1.75 \pm 0.08$ & $8.50 \pm 0.12$ \\
\hline 20 & $3.45 \pm 0.03$ & $2.25 \pm 0.15$ & $2.33 \pm 0.01$ & $1.12 \pm 0.06$ \\
\hline 25 & $4.20 \pm 0.06$ & $2.00 \pm 0.25$ & $2.08 \pm 0.08$ & $4.41 \pm 0.3$ \\
\hline \multicolumn{5}{|c|}{ Peroxidase*U/ml } \\
\hline 5 & $11.12 \pm 0.1$ & $4.00 \pm 0.2$ & $1.02 \pm 0.03$ & $0.96 \pm 0.02$ \\
\hline 10 & $11.48 \pm 0.2$ & $6.68 \pm 0.26$ & $1.34 \pm 0.04$ & $2.88 \pm 0.2$ \\
\hline 15 & $7.16 \pm 0.25$ & $8.20 \pm 0.05$ & $1.24 \pm 0.05$ & $4.68 \pm 0.15$ \\
\hline 20 & $5.68 \pm 0.32$ & $1.69 \pm 0.03$ & $6.64 \pm 0.07$ & $5.52 \pm 0.32$ \\
\hline 25 & $3.64 \pm 0.40$ & $0.62 \pm 0.04$ & $1.62 \pm 0.08$ & $5.78 \pm 0.45$ \\
\hline
\end{tabular}

$*$ indicates each component values are based on the three replicates.

\pm Results were significant at $P<.05$ level by one way ANOVA. 
Table 5:- Effect of Nitrogen on ligninolytic activity of G. lucidum

\begin{tabular}{|c|c|c|c|c|}
\hline \multicolumn{5}{|c|}{ Lignin Degrading Enzymes of G. lucidum } \\
\hline \multicolumn{5}{|c|}{ Laccase*U/ml } \\
\hline Days & $\mathrm{KNO}_{3}$ & $\mathrm{NH}_{4}\left(\mathrm{NO}_{3}\right)_{2}$ & $\mathrm{Ca}\left(\mathrm{NO}_{3}\right)_{2}$ & $\mathrm{NaNO}_{3}$ \\
\hline 5 & $2.38 \pm 0.20$ & $0.95 \pm 0.04$ & $0.96 \pm 0.03$ & $0.42 \pm 0.07$ \\
\hline 10 & $1.75 \pm 0.07$ & $0.45 \pm 0.02$ & $5.04 \pm 0.05$ & $0.52 \pm 0.08$ \\
\hline 15 & $0.62 \pm 0.10$ & $0.36 \pm 0.01$ & $0.47 \pm 0.01$ & $2.00 \pm 0.02$ \\
\hline 20 & $0.51 \pm 0.03$ & $0.30 \pm 0.08$ & $0.24 \pm 0.06$ & $0.21 \pm 0.04$ \\
\hline 25 & $0.45 \pm 0.04$ & $0.20 \pm 0.03$ & $0.44 \pm 0.08$ & $0.16 \pm 0.05$ \\
\hline \multicolumn{5}{|c|}{ Aryl Alcohol oxidase* ${ }^{*} / \mathrm{ml}$} \\
\hline 5 & $1.73 \pm 0.08$ & $0.73 \pm 0.01$ & $0.29 \pm 0.07$ & $0.25 \pm 0.08$ \\
\hline 10 & $2.76 \pm 0.06$ & $0.58 \pm 0.04$ & $0.57 \pm 0.04$ & $0.44 \pm 0.05$ \\
\hline 15 & $1.82 \pm 0.09$ & $0.25 \pm 0.06$ & $0.36 \pm 0.06$ & $0.85 \pm 0.02$ \\
\hline 20 & $1.28 \pm 0.05$ & $0.21 \pm 0.07$ & $0.25 \pm 0.04$ & $0.20 \pm 0.04$ \\
\hline 25 & $0.83 \pm 0.10$ & $0.34 \pm 0.02$ & $0.28 \pm 0.01$ & $0.18 \pm 0.01$ \\
\hline \multicolumn{5}{|c|}{ Lignin Peroxidase* $\mathrm{U} / \mathrm{ml}$} \\
\hline 5 & $4.16 \pm 0.08$ & $9.20 \pm 0.15$ & $2.75 \pm 0.08$ & $1.16 \pm 0.07$ \\
\hline 10 & $7.08 \pm 0.01$ & $3.54 \pm 0.18$ & $2.56 \pm 0.04$ & $2.37 \pm 0.15$ \\
\hline 15 & $2.95 \pm 0.03$ & $2.20 \pm 0.05$ & $1.45 \pm 0.06$ & $5.95 \pm 0.24$ \\
\hline 20 & $2.70 \pm 0.06$ & $1.37 \pm 0.08$ & $1.00 \pm 0.08$ & $1.87 \pm 0.07$ \\
\hline 25 & $2.45 \pm 0.08$ & $2.54 \pm 0.02$ & $0.91 \pm 0.02$ & $1.66 \pm 0.08$ \\
\hline \multicolumn{5}{|c|}{ Peroxidase $* \mathrm{U} / \mathrm{ml}$} \\
\hline 5 & $15.48 \pm 0.20$ & $4.28 \pm 0.05$ & $4.00 \pm 0.1$ & $0.74 \pm 0.03$ \\
\hline 10 & $17.9 \pm 0.10$ & $3.46 \pm 0.03$ & $0.84 \pm 0.02$ & $1.66 \pm 0.08$ \\
\hline 15 & $12.92 \pm 0.23$ & $2.84 \pm 0.07$ & $1.16 \pm 0.05$ & $5.08 \pm 0.2$ \\
\hline 20 & $5.56 \pm 0.32$ & $1.74 \pm 0.09$ & $7.34 \pm 0.2$ & $4.38 \pm 0.1$ \\
\hline 25 & $1.64 \pm 0.12$ & $1.10 \pm 0.02$ & $0.78 \pm 0.02$ & $4.20 \pm 0.5$ \\
\hline
\end{tabular}

$*$ indicates each component values are based on the three replicates.

\pm Results were significant at $P<.05$ level by one way ANOVA

Table 6:- Effect of Nitrogen on ligninolytic activity of $N$. floccosus.

\begin{tabular}{|c|c|c|c|c|}
\hline \multicolumn{5}{|c|}{ Lignin Degrading Enzymes of $N$. floccosus } \\
\hline \multicolumn{5}{|c|}{ Laccase*U/ml } \\
\hline Days & $\mathrm{KNO}_{3}$ & $\mathrm{NH}_{4}\left(\mathrm{NO}_{3}\right)_{2}$ & $\mathrm{Ca}\left(\mathrm{NO}_{3}\right)_{2}$ & NaNO3 \\
\hline 5 & $1.12 \pm 0.05$ & $1.98 \pm 0.05$ & $0.27 \pm 0.08$ & $0.32 \pm 0.04$ \\
\hline 10 & $0.98 \pm 0.10$ & $0.59 \pm 0.02$ & $0.30 \pm 0.05$ & $0.80 \pm 0.05$ \\
\hline 15 & $0.72 \pm 0.03$ & $0.80 \pm 0.06$ & $0.58 \pm 0.07$ & $1.68 \pm 0.07$ \\
\hline 20 & $0.40 \pm 0.04$ & $0.53 \pm 0.04$ & $0.09 \pm 0.02$ & $0.12 \pm 0.04$ \\
\hline 25 & $1.00 \pm 0.06$ & $1.07 \pm 0.08$ & $0.46 \pm 0.01$ & $0.73 \pm 0.08$ \\
\hline \multicolumn{5}{|c|}{ Aryl Alcohol oxidase* U/ml } \\
\hline 5 & $2.00 \pm 0.03$ & $0.98 \pm 0.03$ & $0.11 \pm 0.08$ & $0.25 \pm 0.02$ \\
\hline 10 & $1.32 \pm 0.05$ & $0.28 \pm 0.05$ & $0.16 \pm 0.06$ & $0.52 \pm 0.04$ \\
\hline 15 & $1.26 \pm 0.04$ & $0.38 \pm 0.08$ & $0.21 \pm 0.02$ & $1.03 \pm 0.7$ \\
\hline 20 & $1.21 \pm 0.08$ & $0.25 \pm 0.06$ & $0.29 \pm 0.03$ & $0.28 \pm 0.5$ \\
\hline 25 & $1.14 \pm 0.07$ & $0.73 \pm 0.07$ & $0.70 \pm 0.05$ & $0.28 \pm 0.3$ \\
\hline \multicolumn{5}{|c|}{ Lignin Peroxidase* $\mathrm{U} / \mathrm{ml}$} \\
\hline 5 & $3.70 \pm 0.10$ & $8.00 \pm 0.12$ & $0.62 \pm 0.04$ & $1.87 \pm 0.08$ \\
\hline 10 & $2.16 \pm 0.20$ & $3.87 \pm 0.04$ & $0.54 \pm 0.06$ & $1.83 \pm 0.04$ \\
\hline 15 & $2.00 \pm 0.24$ & $4.70 \pm 0.20$ & $1.75 \pm 0.02$ & $9.79 \pm 0.45$ \\
\hline 20 & $1.41 \pm 0.05$ & $3.75 \pm 0.04$ & $1.45 \pm 0.04$ & $2.70 \pm 0.1$ \\
\hline 25 & $1.45 \pm 0.06$ & $6.20 \pm 0.24$ & $0.08 \pm 0.07$ & $1.00 \pm 0.08$ \\
\hline \multicolumn{5}{|c|}{ Peroxidase* $\mathrm{U} / \mathrm{ml}$} \\
\hline 5 & $12.96 \pm 0.15$ & $5.54 \pm 0.2$ & $0.24 \pm 0.01$ & $0.80 \pm 0.05$ \\
\hline 10 & $10.16 \pm 0.21$ & $4.22 \pm 0.1$ & $0.44 \pm 0.03$ & $1.36 \pm 0.07$ \\
\hline 15 & $8.72 \pm 0.14$ & $4.82 \pm 0.24$ & $0.92 \pm 0.05$ & $6.52 \pm 0.08$ \\
\hline 20 & $2.44 \pm 0.05$ & $2.56 \pm 0.05$ & $8.74 \pm 0.07$ & $4.36 \pm 0.02$ \\
\hline 25 & $2.16 \pm 0.08$ & $4.90 \pm 0.21$ & $0.72 \pm 0.02$ & $1.70 \pm 0.07$ \\
\hline
\end{tabular}

$*$ indicates each component values are based on the three replicates.

\pm Results were significant at $P<.05$ level by one way ANOVA 
Table 7:- Effect of Nitrogen on ligninolytic activity of $F$. flavus

\begin{tabular}{|c|c|c|c|c|}
\hline \multicolumn{5}{|c|}{ Lignin Degrading Enzymes of $F$. flavus } \\
\hline \multicolumn{5}{|c|}{ Laccase*U/ml } \\
\hline Days & $\mathrm{KNO}_{3}$ & $\mathrm{NH}_{4}\left(\mathrm{NO}_{3}\right)_{2}$ & $\mathrm{Ca}\left(\mathrm{NO}_{3}\right)_{2}$ & $\mathrm{NaNO}_{3}$ \\
\hline 5 & $0.82 \pm 0.05$ & $0.25 \pm 0.02$ & $0.36 \pm 0.02$ & $1.07 \pm 0.07$ \\
\hline 10 & $0.94 \pm 0.03$ & $5.65 \pm 0.40$ & $8.24 \pm 0.04$ & $1.44 \pm 0.03$ \\
\hline 15 & $1.33 \pm 0.10$ & $6.32 \pm 0.50$ & $0.26 \pm 0.05$ & $5.01 \pm 0.02$ \\
\hline 20 & $1.63 \pm 0.04$ & $1.46 \pm 0.02$ & $0.24 \pm 0.01$ & $8.83 \pm 0.04$ \\
\hline 25 & $0.70 \pm 0.02$ & $1.86 \pm 0.08$ & $0.14 \pm 0.08$ & $0.81 \pm 0.05$ \\
\hline \multicolumn{5}{|c|}{ Aryl Alcohol oxidase* U/ml } \\
\hline 5 & $1.23 \pm 0.06$ & $0.21 \pm 0.02$ & $0.16 \pm 0.03$ & $0.22 \pm 0.03$ \\
\hline 10 & $2.63 \pm 0.08$ & $1.90 \pm 0.04$ & $0.86 \pm 0.06$ & $1.26 \pm 0.01$ \\
\hline 15 & $2.53 \pm 0.04$ & $1.35 \pm 0.01$ & $0.39 \pm 0.02$ & $0.70 \pm 0.05$ \\
\hline 20 & $2.40 \pm 0.03$ & $0.68 \pm 0.08$ & $0.25 \pm 0.04$ & $0.70 \pm 0.06$ \\
\hline 25 & $2.34 \pm 0.20$ & $0.96 \pm 0.04$ & $0.24 \pm 0.08$ & $0.43 \pm 0.07$ \\
\hline \multicolumn{5}{|c|}{ Lignin Peroxidase* U/ml } \\
\hline 5 & $2.33 \pm 0.05$ & $3.25 \pm 0.15$ & $0.91 \pm 0.01$ & $10.62 \pm 0.48$ \\
\hline 10 & $7.33 \pm 0.02$ & $21.37 \pm 0.23$ & $2.54 \pm 0.04$ & $11.54 \pm 0.78$ \\
\hline 15 & $5.70 \pm 0.08$ & $13.83 \pm 0.35$ & $2.04 \pm 0.06$ & $8.70 \pm 0.83$ \\
\hline 20 & $5.29 \pm 0.06$ & $5.54 \pm 0.05$ & $1.75 \pm 0.01$ & $3.00 \pm 0.2$ \\
\hline 25 & $4.83 \pm 0.07$ & $6.83 \pm 0.08$ & $1.33 \pm 0.05$ & $6.50 \pm 0.5$ \\
\hline \multicolumn{5}{|c|}{ Peroxidase* ${ }^{*} / \mathrm{ml}$} \\
\hline 5 & $10.83 \pm 0.24$ & $2.68 \pm 0.05$ & $0.50 \pm 0.02$ & $2.08 \pm 0.08$ \\
\hline 10 & $14.0 \pm 0.34$ & $7.10 \pm 0.07$ & $1.52 \pm 0.04$ & $2.94 \pm 0.01$ \\
\hline 15 & $10.00 \pm 0.24$ & $3.84 \pm 0.02$ & $1.12 \pm 0.05$ & $2.72 \pm 0.04$ \\
\hline 20 & $6.16 \pm 0.12$ & $1.16 \pm 0.04$ & $8.48 \pm 0.06$ & $3.06 \pm 0.07$ \\
\hline 25 & $2.48 \pm 0.05$ & $0.64 \pm 0.01$ & $0.60 \pm 0.01$ & $3.00 \pm 0.03$ \\
\hline
\end{tabular}

$*$ indicates each component values are based on the three replicates.

\pm Results were significant at $P<.05$ level by one way ANOVA.

\section{Discussion:-}

Isolation and identification of fungi:-

Arya et al. (2008) reported that Lenzites sterioides was recorded for the first time on T. grandis. Thirty species of lignicolous fungi belonging to Ascomycetes and Basidiomycete are reported from the Ratanmahal Wildlife Sanctuary, Gujarat, India. The new species are Coriolus versicolor, Coriolopsis gallica, Daedalea quercina F. resupinate, D. unicolor var. hydnoidea, Fomitopsis rosea, Hypodontia comptopsis and Lenzites betulina F. varigatum is reported for the first time from India (Nagadesi and Arya 2014). In the present paper different lignicolous fungi like S. commune, L. sterioides, G. lucidum, N. floccosus, and F. flavus were also isolated.

\section{Enzymatic test:-}

Wood-inhabiting fungi were isolated from living trees and fallen branches collected from Ratanmahal Wildlife Sanctuary, Gujarat, India. The lignocellulolytic activity of wood rotting fungi was identified after isolation. The highest ligninolytic activity was shown by G. lucidum and lowest by L. betulina (Nagadesi and Arya 2012). In the present papers also the highest ligninolytic activity was shown by G. lucidum. Highest laccase activity and peroxidase activity was shown by G. lucidum and lowest by $S$. commune. The highest cellulolytic activity was shown by Basidiomycota members. Lowest cellulolytic activity was shown by L. betulina (Nagadesi and Arya 2012). In the present paper the lignicolous fungi were able to produce lignin modifying enzymes like laccase, lignin peroxidase, aryl alcohol oxidase, and peroxidase

\section{Effect of Nitrogen on growth of wood decay fungi:-}

Ammonium nitrate $(12.5 \mathrm{mM})$, which was used in the basal medium, was replaced by various inorganic nitrogen sources - $\left(\mathrm{NH}_{4}\right)_{2} \mathrm{SO}_{4}, \mathrm{NaNO}_{3}, \mathrm{KNO}_{3}, \mathrm{NH}_{4} \mathrm{Cl}$ and ammonium tartarate - and organic nitrogen sources at $1 \%$ (w/v) peptone and yeast extract. $\left(\mathrm{NH}_{4}\right)_{2} \mathrm{SO}_{4}$ which was found to be the best nitrogen source for Aspergillus sp. SIP 11 was tried at-different levels ( $2 \mathrm{mM}$ to $20 \mathrm{mM})$ in the medium to ascertain the optimum level for maximum activity 
(Ahammed 2002). In the present study Calcium nitrate for S. commune, Sodium nitrate for L. sterioides, Potassium nitrite for G. lucidum, Ammonium nitrate for $F$. flavus and Potassium nitrite for $N$. floccosus was found best nitrogen source. In $S$. commune maximum growth (46.0 mg mycelial dry weight) was observed on twelfth day of incubation (Shanmugapriya et al. 2013). But in the present study the S. commune showed maximum growth $259 \mathrm{mg}$ of mycelia dry weight in 10 days. In L. eximia maximum growth (44.0 mg mycelial dry weight) was observed on twelfth day (Shanmugapriya et al. 2013). But in the present study the $L$. sterioides showed maximum growth $290 \mathrm{mg}$ of mycelia dry weight in 10 days.

\section{Enzyme essay:-}

S. commune showed LiP (177 U/ml), and AAO (190 U/ml) were maximum on seventh day. After the optimum period the productions were gradually decreased (Shanmugapriya et al. 2013). But in present study S. commune showed $\mathrm{LiP}(45.50 \mathrm{U} / \mathrm{ml})$, and AAO $(6.85 \mathrm{U} / \mathrm{ml})$ was maximum on twenty days. Among the nitrogen sources, diammonium tartarate at $0.66 \mathrm{~g} / \mathrm{l}$ concentration favored mycelial growth of $P$. chrysosporium. But LiP, and AAO production were favored at $0.66 \mathrm{~g} / \mathrm{l}$ of diammonium tartrate. The optimum mycelial growth of $\mathrm{S}$. commune was obtained at $0.66 \mathrm{~g} / \mathrm{l}$ of diammonium tartrate with maximum production of $\mathrm{LiP}$ at $0.44 \mathrm{~g} / \mathrm{l}$ concentration of diammonium tartrate whereas AAO was favored at $0.66 \mathrm{~g} / \mathrm{l}$, concentration of urea Shanmugapriya et al. (2013). But in the present study the maximum production of $\mathrm{LiP}$ and $\mathrm{AAO}$ was favored $\mathrm{NH}_{4}\left(\mathrm{NO}_{3}\right)_{2}$ as sole nitrogen source. There is increasing in ligninolytic enzyme activities by white rot basidiomycetes in nitrogen sufficient media (Kaal et al. 1995). Nutritional variables like nitrogen significantly influence the production of ligninolytic enzymes by white rot fungi (Pascal et al., 1991). Lignin peroxidase (LiP) synthesis by S. commune, Phanerochaete chrysosporium and Phanerochaete sordida is inhibited by high nitrogen contents but laccase production by most white rot fungi is higher in high-nitrogen $(24 \mathrm{mM})$ cultures as compared to those in low-nitrogen $(2.4 \mathrm{mM})$ (Boyle et al., 1992; Trevor, 1999). But In the present study high nitrogen content is not inhibited LiP activity by S. commune and laccase activity was more i. e. $6.71 \mathrm{U} / \mathrm{ml}$ in $\mathrm{Ca}\left(\mathrm{NO}_{3}\right)_{2}$ as sole nitrogen source.

$\mathrm{LiP}$, and AAO production by L. eximia were maximum on seventh day and it was found to be $170 \mathrm{U} / \mathrm{ml}$, and 165 $\mathrm{U} / \mathrm{ml}$. After the optimum period the productions were gradually decreased (Shanmugapriya et al. 2013). But in present study the L. sterioides showed LiP, activity $(15.79 \mathrm{U} / \mathrm{ml})$ and AAO activity $(1.82 \mathrm{U} / \mathrm{ml})$ was maximum on tenth and fifteenth day respectively. For L. eximia maximum mycelia growth was favored at $0.66 \mathrm{~g} / \mathrm{l}$ of tryptone. LiP was found to be maximum at a concentration of $0.66 \mathrm{~g} / \mathrm{l}$ of Urea, AAO was favored at a maximum concentration of $0.66 \mathrm{~g} / \mathrm{l}$ of diammonium tartrate (Shanmugapriya et al. 2013). But in present study the maximum LiP and AAO was found in $\mathrm{NH}_{4}\left(\mathrm{NO}_{3}\right)_{2}$ and $\mathrm{NaNO}_{3}$

$\mathrm{NH}_{4} \mathrm{NO}_{3}$ was the optimum nitrogen source for laccase activity shown by G. lucidum (Stajic et al 2010). During submerged fermentation of wheat bran by G. lucidum (Songulashvili et al 2007) noted maximum lac activity in the presences of $\mathrm{KNO}_{3}$ at a nitrogen concentration of $10 \mathrm{~mm}$. while $\mathrm{NH}_{4} \mathrm{NO}_{3}$ was less suitable nitrogen source for laccase activity. But in present study the $\mathrm{Ca}\left(\mathrm{NO}_{3}\right)_{2}$ was found to be nitrogen source for laccase activity by $G$. lucidum. But organic nitrogen source like peptone were the best for laccase activity in many mushroom species like P. ostretus (Levin et al 2010). Ding et al. (2012) reported that laccase synthesis by G. lucidum was appreciable at high nitrogen concentrations using yeast extract as nitrogen source. Yeast extract has been known to stimulate laccase synthesis and our results are in concordance with optimal culture condition for G. lucidum (Ding et al., 2012). But in present study the inorganic nitrogen source was suitable for laccase activity by G. lucidum.

High amounts of organic nitrogen source enhanced the production of ligninolytic enzymes (Asghar et al., 2006). But in the present study the lignicolous fungi showed ligninolytic activity in inorganic nitrogen source. Absence of nitrogen stimulated enzyme production in $P$. chrysosporium while Phanerochaete sp. needed additional nitrogen (Asghar et al., 2006). But in present study the lignicolous fungi showed ligninolytic enzyme production when nitrogen source is present. Both $P$. eryngii and $P$. ostreatus produced highest Lac activity with $\left(\mathrm{NH}_{4}\right)_{2} \mathrm{SO}_{4}$ as a nitrogen source at 20-30 mM nitrogen content (Stajic et al., 2006). But in the present study the laccase activity was maximum in $\mathrm{NH}_{4}\left(\mathrm{NO}_{3}\right)_{2}$. P. ostreatus and P. pulmonarius produced higher activities of LiP in the presence of $0.5 \%$ peptone with $30 \mathrm{mM}$ nitrogen content (Stajic et al., 2006). But in the present study the LiP activity was maximum in $\mathrm{NH}_{4}\left(\mathrm{NO}_{3}\right)$. The production of laccase enzyme by $F$. flavum in low nitrogen medium was reported by Raghukumar et al (2006). But in present study highest laccase activity was in case of $\mathrm{NaNO}_{3}$ whereas lowest in case of $\mathrm{Ca}\left(\mathrm{NO}_{3}\right)_{2}$.

\section{Acknowledgements:-}

The authors are thankful to the Head, Department of Botany, The M S University of Baroda for laboratory facilities 


\section{References:-}

1. Ahammed S, (2002) Production and Characterization of lignin peroxidases from Mangrove Ascomvcetes. Ph.D Thesis submitted to Cochin University of Science and Technology

2. Ander P, Eriksson KE, (1978) Lignin degradation and utilization by microorganisms. Prog. Ind. Microbiol. 14:1-58.

3. Asghar M, Asad MJ, Legge RL, (2006) Enhanced lignin peroxidase synthesis by Phanerochaete chrysosporium in solid state bioprocessing of a lignocellulosic substrate. World J. Microbiol. Biotechnol. 22: 449-453.

4. Bains R. K, Rahi D.K., and hoondal G. S. 2006. Evaluation of wood degrading enzymes of some indigenous white rot fungi. J. Mycol. Pl. Pathol. 36(2):161-164.

5. Boyle CD, Kropp BR, Reid ID (1992) Solubilization and mineralization of lignin by white rot fungi. Appl Environ Microbiol 58:3217-3224

6. Coll PM, Fernandez-Abalos JM, Villanueva JR, Santamaria R, Perez P, (1993) Purification and characterization of a phenoloxidase (laccase) from the lignin degrading basidiomycete PM1 (CECT 2971). Appl. Environ. Microbiol. 59: 2607- 2613.

7. Daniel G, Vole J, Kubatova E, (1994) Pyranose oxidase, a major source of $\mathrm{H}_{2} \mathrm{O}_{2}$ during wood degradation by Phanerochaete chrysosporium, Trametes versicolor, and Oudemansiella mucida. Appl. Environ. Microbiol. 60:2524-2532.

8. De Jong E, Field JA, de Bont JAM, (1994) Aryl alcohols in the physiology of ligninolytic fungi. FEMS Microbiol. Rev.13: 153-188.

9. Ding Z, Chen Y, Xu Z, Peng L, Xu G, Gu Z, Zhang L, Shi G, Zhang K, (2012) Production and characterization of thermo stable laccase form the mushroom Ganoderma lucidum, using submerged fermentation. Afr. J. Microbiol. Res. 6: 1147-1157.

10. Eggert CU, Temp J, Dean FD, Eriksson KEL (1996) A fungal metabolite mediates degradation of non phenolic lignin structures and synthetic lignin by laccase. FEBS Lett. 391:144-148.

11. Fukushima Y, Kirk KT, (1995) Laccase component of the Ceriporiopsis subvermispora lignin-degrading system. Appl Environ Microbiol 61:872-876.

12. Gadd GM, (2001). Fungi in Bioremediation. Cambridge University Press, Cambridge, U.K. Pp. 481. ISBN 0521-78119-1 (hardback)

13. Hacskaylo J, Lilly LG, and Barnett HL, (1954) Growth of fungi on three sources of nitrogen. Mycologia 46: 691-701.

14. Harkin JM, Obst JR, (1973) Syringal-dazine, an effective reagent for detecting laccase and peroxidase in fungi. Experientia 29: 381- 387.

15. Hernandez-Ortega A, Ferreira P, Martínez AT, (2012) Fungal aryl-alcohol oxidase: a peroxide-producing flavor-enzyme involved in lignin degradation. Appl Microbiol Biotechnol. 93: 1395-1410.

16. Hildén K, Hakala TK, Maijala P, Lundell TK, Hatakka A, (2007) Novel thermotolerant laccases produced by the white-rot fungus Physisporinus rivulosus. Appl. Microbiol Biotechnol. 77: 301-309.

17. Jurasek L, Varadi J, Sopko R, (1967) Enzymic properties of the lignolytically active supernatant of Schizophyllum commune shake culture. Drev. Vysk. 12: 191-201.

18. Kaal EEJ, Field JA, Joyce TW, (1995) Increasing ligninolytic enzyme activities in white rot basidiomycetes by nitrogen sufficient media. Bioresour. Technol, 53: 133-139,

19. Kelley RL, Reddy CA, (1986) Identification of glucose oxidase activity as the primary source of hydrogen peroxide production in ligninolytic cultures of Phanerochaete chrysosporium. Arch. Microbiol. 144:248-253.

20. Kersten PJ, Kirk TK, (1987) Involvement of a new enzyme, glyoxal oxidase, in extracellular H2O2 production by Phanerochaete chrysosporium. J. Bacteriol. 169:2195-2201.

21. Leatham GF, Stahmann MA, (1981) Studies on laccase of Lentinus edodes: specificity, localization and association with the development of fruiting bodies. Journal of General Microbiology 125: 147-157.

22. Leonowicz A, Cho NS, Luterek J, Wilkolazka A, Wojtas-Wasilewska M, Matuszewska A, Hofrichter M, Wesenberg D, Rogalski J (2001) Fungal laccase: properties and activity on lignin. J Basic Microbiol 41:185227.

23. Levin L, Melignani E, Ramos AM, (2010) Effect of nitrogen source and vitamins on ligninolytic enzymes production by some white rot fungi. Dye decolorization by selected culture filtrates. Bioresource Technol. 101: 4554-4563.

24. Lewis NG, Razal RA, Yamamoto E, (1987) Lignin Degradation by Peroxidase in Organic Media: A Reassessment. Proceedings of the National Academy of Sciences of the United States of America 84 (22): 7925-7927 
25. Mansur M, Arias ME, Copa Patino JL, Flardh M, Gonza'lez1 AE, (2003) The white-rot fungus Pleurotus ostreatus secretes laccase isozymes with different substrate specificities. Mycologia, 95(6):1013-1020.

26. Masaphy S, Levanon D. (1992) The effect of lignocellulose on lignocellulolytic activity of Pleurotus pulmonarius in submerged culture. Appl. Microbiol. Biotechnol. 36:828-832.

27. Muheim A, Leisola MSA, Schoemaker HE, Waldner R, Sanglard D, Reiser J, (1991) Purification and properties of an aryl-alcohol dehydrogenase from the white-rot fungus Phanerochaete chrysosporium. Eur. J. Biochem. 195:369-375.

28. Nagadesi P. K., and Arya A (2014). New records of Lignicolous fungi from Ratanmahal Wildlife Sanctuary, Gujarat, India. International letters of Natural Science 8:23-29 ISSN 2300-9675

29. Nagadesi P. K, and Arya A (2012). Lignocellulolytic activity of Wood-inhabiting Fungi from Ratanmahal Wildlife Sanctuary Gujarat, India. Advanced biotech. 12 (5): 30-36.

30. Nishida A, Eriksson KE, (1987) Formation, purification, and partial characterisation of methanol oxidase, a $\mathrm{H}_{2} \mathrm{O}_{2}$-producing enzyme in Phanerochaete chrysosporium. Biotechnol. Appl. Biochem. 9:325-338.

31. Nobles M. K. 1964. Identification of cultures of Wood Inhabiting Hymenomycetes. Canadian Journal of Botany. 43:1097-1139.

32. Pascal B, Perez J, Jeffries TW, (1991) Regulation of Ligninase Production in White-Rot Fungi. Enzymes in biomass conversion, Proceedings of a symposium. Boston, MA. ACS symposium series 460. Am. Chem. Soc. p. 6.

33. Perez J, Munoz-Dorado J, de la Rubia T, Martinez J, (2002) Biodegradation and biological treatments of cellulose, hemicellulose and lignin: an overview. Int. Microbiol 5: 53-63.

34. Raghukumar C, Shailaja MS, Parameswaran PS, Singh SK, (2006) Removal of polycyclic aromatic hydrocarbons from aqueous media by the marine fungus NIOCC\#312: involvement of lignin degrading enzymes and exopolysaccharides. Indian Journal of marine Science 35 (4): 373-379.

35. Shanmugapriya M, Lakshmiprabha M, (2013) Optimization and xenobiotics degradation of newly isolated white rot fungi, Species, 3(7), 4-11,

36. Shraddha RS, Sehgal S, Kamthania M, Kumar A, (2011) Laccase: Microbial Sources, Production, Purification, and Potential Biotechnological Applications. Enzyme Res. Volume 2011, Article ID 217861, 11 page

37. Songulasvili G, Elisashvili V, Wasser SP, Nevo E, Hadar Y, (2007) Basidiomycetes laccase and manganese peroxidase activity in submerged fermentation of food industry wastes Enzyme Microb. Technol. 41:57-61.

38. Sopko R, (1968) Influence of extractives on cellulase and xylanase activities of Schizophyllum commune. Drev. vysk. 13: 571 - 574.

39. Stajic M, kukavica B, Vukojevic J, Simonic j, Veljovic- jovanovic S, Duletic- lausevis S, (2010) Wheat straw conversion by enzymatic system of Ganoderma lucidum. Bio Resource 5(4): 2362-2373

40. Stajic M, Persky L, Friesem D, Hadar Y, Wasser SP, Nevo E, Vukojevic j. (2006) Effect of different carbon and nitrogen sources on laccase and peroxidase production by selected pleurotus species. Enzyme Microb. Technol. 38: 65-73

41. Tien M, Kirk TK, (1984) Lignin-degrading enzyme from Phanerochaete chrysosporium: purification, characterization, and catalytic properties of a unique H2O2-requiring oxygenase. Proc Natl Acad Sci USA 81, 2280-2284

42. Teather R. M and Wood P. J. 1982. Use of Congo red polysaccharide interaction of cellulolytic bacteria from the bovine serum. Appl. Environ. Microbiol. 43:777-780.

43. Trevor MD, Carlos SM, Adinarayana RC, (1999) Lignin - Modifying Enzymes of the White Rot Basidiomycete Ganoderma lucidum. Appl. Environ. Microbiol. 65(12):5307-5313.

44. Varela E, Martınez AT, Martınez MJ, (2000) Southern blot screening for lignin peroxidase and aryl-alcohol oxidase genes in 30 fungal species. Journal of Biotechnology 83:245-251

45. Vasconcelos AFD, Barbosa AM, Dekker RFH, Scarminio IS, Rezende MI, (2000) Optimization of laccase production by Botryosphaeria sp. In the presence of veratryl alcohol by the response surface method. Process. Biochem. 35: 1131-1138.

46. Zeller SM, Schmitz H, Duggar BM, (1916) Studies in the physiology of the fungi. VII. Growth of wooddestroying fungi on liquid media. Ann. Missouri Botan. Garden 6:137-142. 